\title{
Shaking Table Test of a RC Frame with EPSC Latticed Concrete Infill Wall
}

\author{
Baizan Tang, ${ }^{1}$ Xiaojun Li, ${ }^{1}$ Su Chen, ${ }^{1}$ and Lihong Xiong ${ }^{2}$ \\ ${ }^{1}$ Institute of Geophysics, China Earthquake Administration, Beijing 100081, China \\ ${ }^{2}$ Institute of Engineering Mechanics, China Earthquake Administration, Harbin 150080, China
}

Correspondence should be addressed to Xiaojun Li; beerli@vip.sina.com

Received 8 February 2017; Revised 29 April 2017; Accepted 4 May 2017; Published 22 June 2017

Academic Editor: Abdollah Shafieezadeh

Copyright (C) 2017 Baizan Tang et al. This is an open access article distributed under the Creative Commons Attribution License, which permits unrestricted use, distribution, and reproduction in any medium, provided the original work is properly cited.

The expansive polystyrene granule cement (EPSC) latticed concrete wall is a new type of energy-saving wall material with loadbearing, insulation, fireproof, and environmental protection characteristics. A series of shaking table tests were performed to investigate the seismic behavior of a full-scale reinforced concrete (RC) frame with EPSC latticed concrete infill wall, and data obtained from the shaking table test were analyzed. The experimental results indicate that the designed RC frame with EPSC latticed concrete infill wall has satisfactory seismic performance subjected to earthquakes, and the seismic responses of the model structure are more sensitive to input motions with more high frequency components and long duration. The EPSC latticed concrete infill wall provided high lateral stiffness so that the walls can be equivalent to a RC shear wall. The horizontal and vertical rebar, arranged in the concrete lattice beam and column, could effectively restrain the latticed concrete infill wall and RC frame. To achieve a more comprehensive evaluation on the performance of the $\mathrm{RC}$ frame with latticed concrete infill walls, further research on its seismic responses is expected by comparing with conventional infill walls and nonlinear analytical method.

\section{Introduction}

Reinforced concrete (RC) frames with brick or block masonry infill walls are commonly found in most parts of Europe and in other places around the world [1-3], including China. They are generally constructed for residential and commercial purposes. In recent years, negative effects have been observed in recent earthquakes, for example, in 2014 Mae Lao earthquake [4], 2011 Lorca earthquake [5], 2009 L'Aquila earthquake [6, 7], 2008 Wenchuan earthquake [8], 2007 Pisco-Chincha earthquake [9], and 2006 L'Aquila earthquake [10], which highlighted the vulnerability of RC frames with infill walls.

Moreover, in order to maintain the sustainable development of the environment and accelerate the urbanization process, China has carried out the reform program of wall materials and restricted solid clay brick [11]. Hence, it is imperative to introduce or develop new kinds of wall material and explore the application prospect.

In recent years, expansive polystyrene granule cement (EPSC) latticed concrete wall was put forward due to its lightweight, load-bearing, insulation, fireproof, energysaving, and environmental protection characteristics [12-15]. The wall material is based on EPSC elements; when these elements are assembled into a wall, they have a network of cylindrical cavities and provide a formwork for the liquid reinforced concrete. The walls are similar to conventional reinforced concrete block masonry in construction but more monolithic like reinforced concrete walls in behavior and function similarly to a stiffened plate [16]. Detailed drawings of the EPSC latticed concrete components are shown in Figure 1. Figure 2 shows the skeleton of latticed concrete wall after removing the EPSC.

Further researches have carried out on the latticed concrete wall. Based on modified plate bending theory, Shugar [16] proposed a preliminary analytical approach for the vertical and lateral load capacity of latticed concrete walls and performed model structural tests on the walls to verify the analytical methodology. Steady-state hot-box tests and finite difference simulation were done to examine the steady-state thermal performance of the EPSC latticed concrete wall [12]. Nowadays, cyclic lateral loading tests have been performed to 


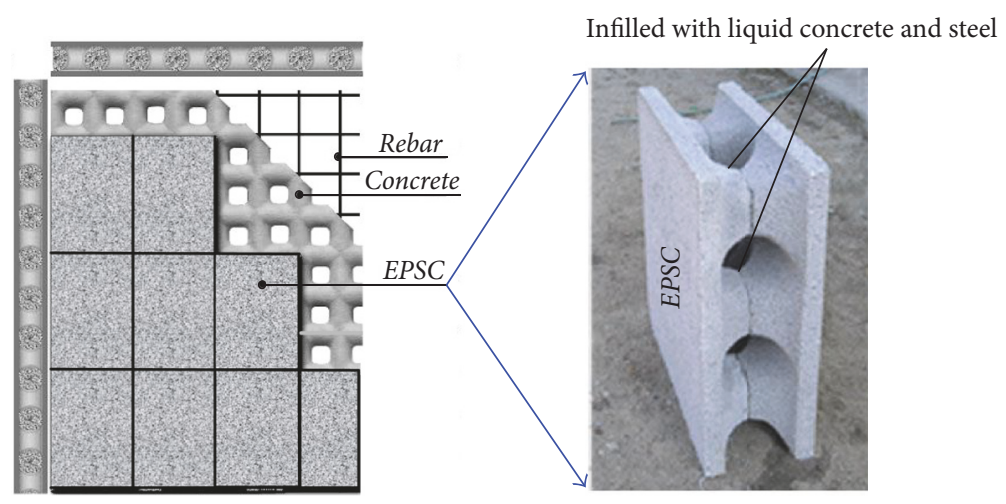

FIGURE 1: EPSC latticed concrete wall.

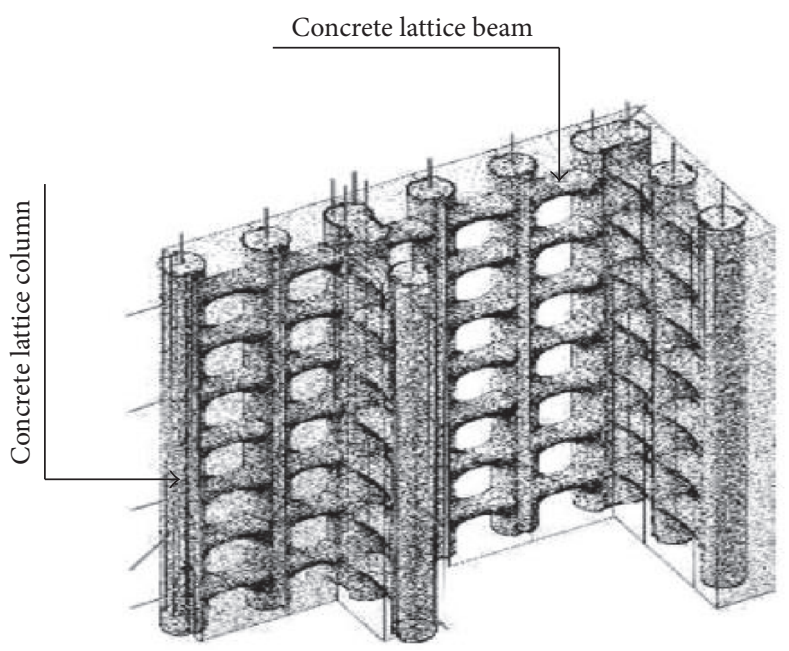

FIGURE 2: Skeleton of latticed concrete wall.

investigate the seismic performance of EPSC latticed concrete wall and check the current design and analysis methods. Sun et al. [17] studied the seismic behaviors of concrete grill wall through the testing of 8 pieces of latticed concrete wall with shear span ratio of $0.77,0.84$, and 1.0 under the action of vertical load and cyclic lateral load. China Academy of Building Research conducted a series of cyclic lateral loading tests on latticed concrete wall and full-scale structure and established the technical specification for dwelling houses with EPSC latticed concrete wall [14]. Zhou et al. [18] conducted a series of cyclic lateral loading tests on latticed concrete wall to investigate effects of different aspect ratios on the seismic behavior. Chen et al. [19] presented the numerical simulation results of EPSC latticed concrete wall in the vertical and horizontal load. The calculated results indicated that the stress distribution of seismic wall was uniform.

These studies focus on the physical and mechanical performance of EPSC latticed concrete wall. Few shaking table test results or numerical simulations are available in the literature on seismic performance of RC frame with EPSC latticed concrete infill wall. In view of this, a series of shaking table tests on full-scaled RC frame structure with EPSC latticed concrete infill walls were carried out to investigate the seismic performance of the structure, and the experimental data were analyzed in this paper.

\section{Shaking Table Test}

2.1. Design and Construction of the Test Model. The test model is a single story RC frame structure with EPSC latticed concrete infill wall. It is supported by a rigid RC base beam fastened to a shake table. The test model before testing and its dimension data are shown in Figure 3. For infill walls, EPSC with nominal dimension corresponding to $0.9 \mathrm{~m} \times$ $0.6 \mathrm{~m} \times 0.25 \mathrm{~m}$ (length $\times$ width $\times$ height) was used. The cross section of concrete lattice beam and column is circular with a diameter of $0.16 \mathrm{~m}$. The spacing of the concrete lattice beams or columns is $0.3 \mathrm{~m}$, as shown in Figure 4 .

The concrete strength grade used in the latticed concrete infill wall and RC frame is C15 and C40. Before testing, the compression test of specimen with size of $150 \mathrm{~mm} \times$ $150 \mathrm{~mm} \times 150 \mathrm{~mm}$ and elasticity modulus test of specimen with size of $150 \mathrm{~mm} \times 150 \mathrm{~mm} \times 300 \mathrm{~mm}$ were conducted. The average concrete compressive cube strength $f_{\text {cu }}$ was measured at approximately $43.87 \mathrm{MPa}$ for the frame structure and $10.62 \mathrm{MPa}$ for the latticed concrete infill wall. The 


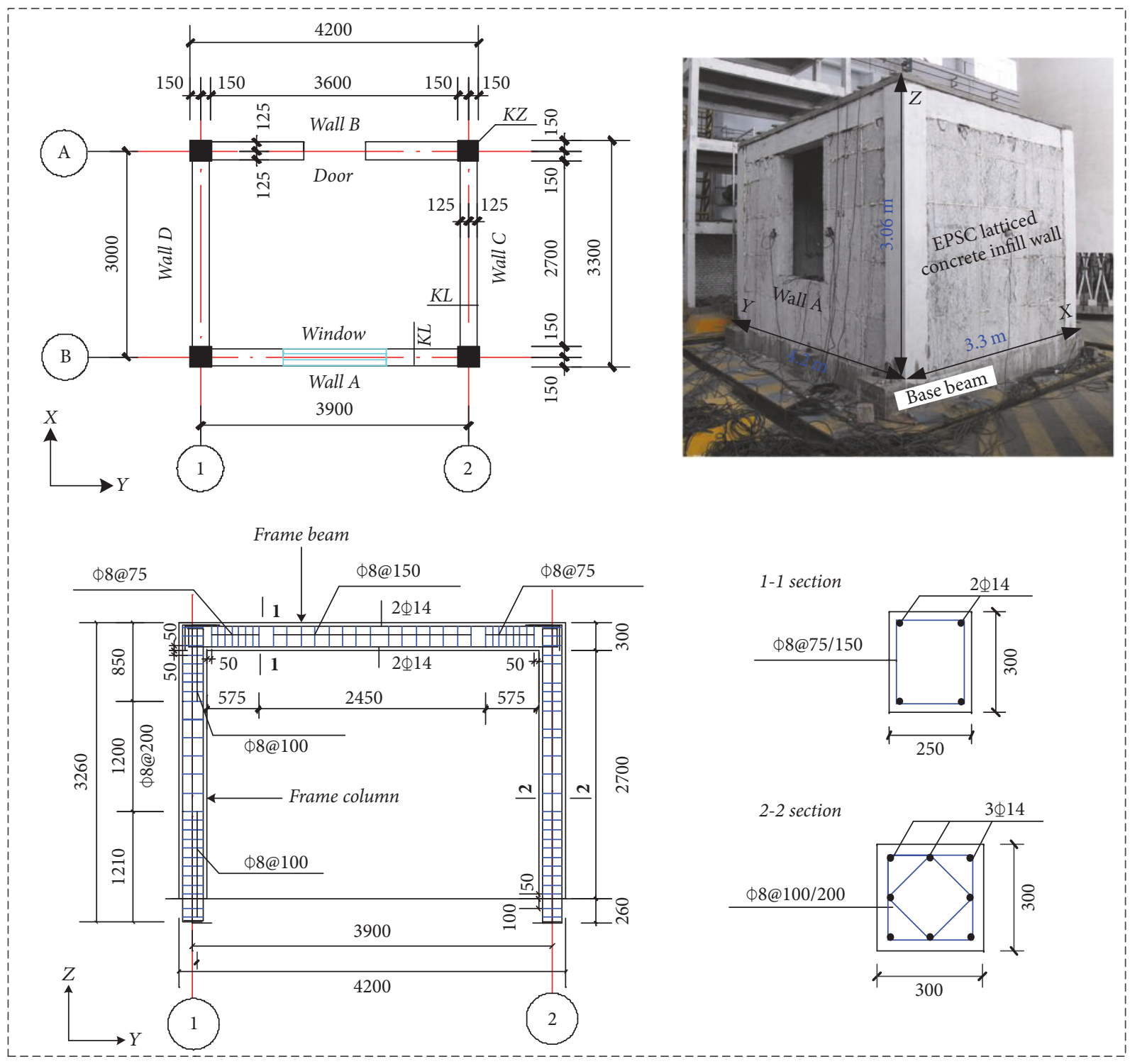

FIGURE 3: Picture and dimension of the model structure.

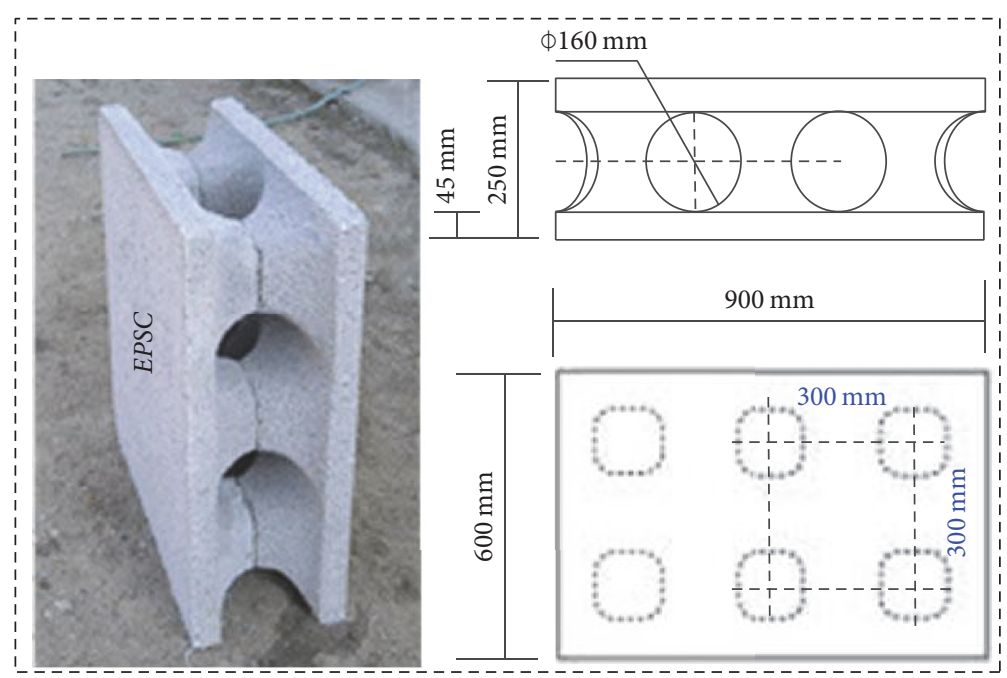

FIgURE 4: Specification and dimension of EPSC. 


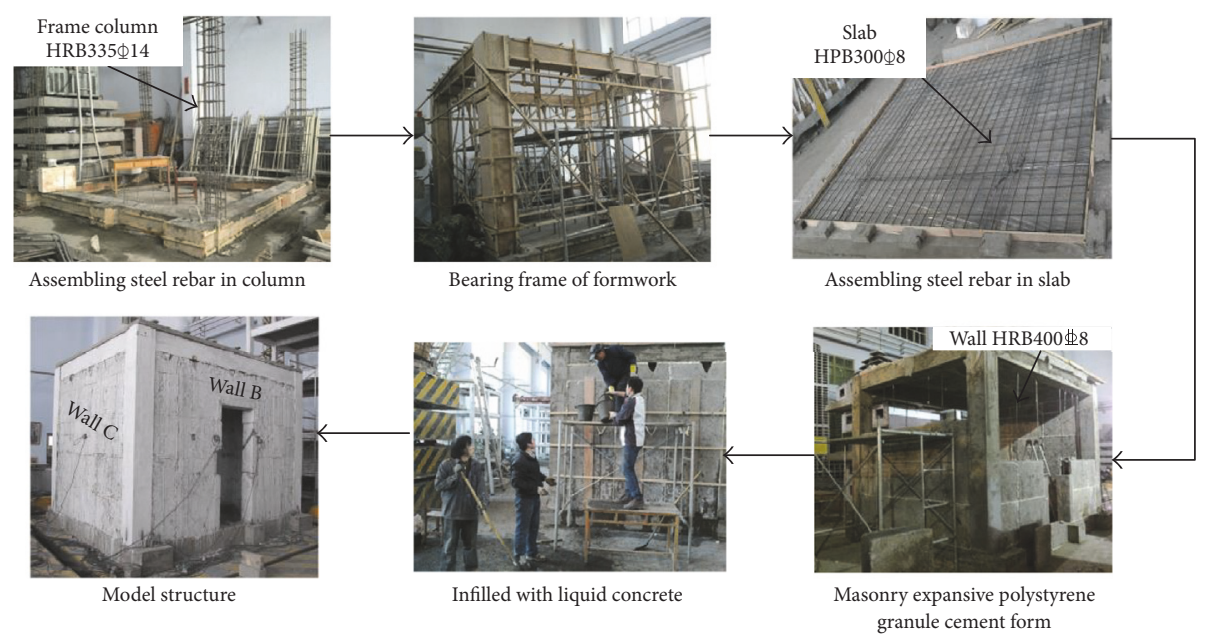

FIGURE 5: Construction process of the model structure.

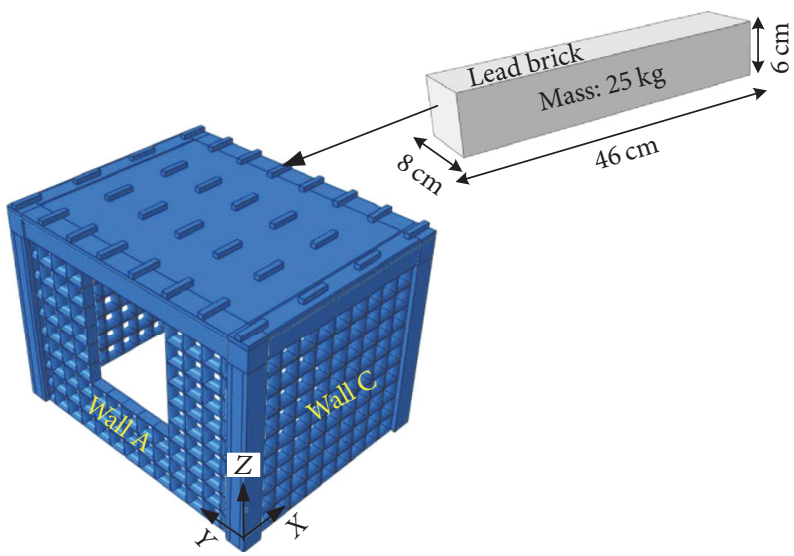

FIGURE 6: Distribution of additional weight on the model structure.

corresponding elasticity modulus is approximately $33 \mathrm{GPa}$ for the frame concrete and $20 \mathrm{GPa}$ for the latticed concrete. The tensile cube strength of concrete-like materials is generally equal to about $1 / 10$ compressive cube strength by the code for design of concrete structures [20]. The yield stresses are $335 \mathrm{MPa}$ (HRB335) for the rebar embedded in the frame structure, $400 \mathrm{MPa}$ (HRB400) for that in the latticed concrete infill wall, and $300 \mathrm{MPa}$ (HPB300) for that in the slab, as shown in Figure 5 . The material physical parameters of test frame structure are shown in Tables 1 and 2. Considering the effect of live load on the slab, $1500 \mathrm{~kg}$ additional mass was added to the test model. Rectangle lead bricks $(46 \mathrm{~cm} \times 8 \mathrm{~cm}$ $\times 6 \mathrm{~cm}$ ) were grouted on the model structure as additional mass. Figure 6 illustrates the distribution of the rectangle lead bricks on the model structure.

2.2. Test Device. The seismic response test of a $\mathrm{RC}$ frame structure with EPSC latticed concrete wall was performed by the shaking table at the Institute of Engineering Mechanics, China Earthquake Administration, Harbin, China. The dimension of the shaking table is $5.0 \mathrm{~m} \times 5.0 \mathrm{~m}$ in plane. The maximum working load of the table is $300 \mathrm{KN}$, and the maximum overturning moment is $750 \mathrm{KN} \cdot \mathrm{m}$. The shaking table can achieve maximum acceleration of $1.0 \mathrm{~g}$ in horizontal directions and $0.7 \mathrm{~g}$ in vertical direction. The displacement limits of the table are $\pm 80 \mathrm{~mm}$ in the horizontal directions and $\pm 50 \mathrm{~mm}$ in vertical direction. The working frequency of the table ranges from 0.5 to $40 \mathrm{~Hz}$. A data acquisition system with 128-channel transducers was used to collect the data in the test.

2.3. Layout of Sensors. A total of 14 force-balance accelerometers and 8 displacement transducers were used to measure the global responses of the structure. 48 strain gauges, including 44 steel strain gauges and 4 concrete strain gauges (measuring points S-A11, S-B16, S-C8, and S-C9), were used to measure the strain responses of the latticed concrete infill wall. The accelerometers have a frequency response of $0-80 \mathrm{~Hz}$ and measuring range of $\pm 5 \mathrm{~g}$, while displacement transducers can measure up to $100 \mathrm{~mm}$. Based on the calibration for the strain gauges, the resistance value is $120 \pm 0.2 \Omega$. Sensors are shown in Figure 7.

The displacement transducers were installed along the structural height from the base beam to the slab, in which 


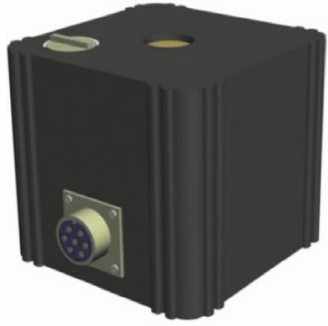

Force-balance accelerometer

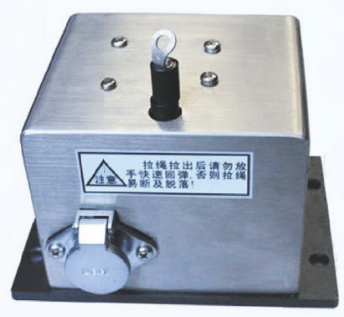

Displacement transducer

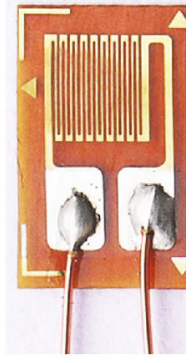

Strain gauge

Figure 7: Sensors used in the shaking table test.

TABLE 1: Concrete compressive cube strength of frame structure.

\begin{tabular}{lcccccc}
\hline Specimen & 1 & 2 & 3 & 4 & 5 & 5 \\
\hline$f_{\mathrm{cu}}(\mathrm{MPa})$ & 44.44 & 44.45 & 42.47 & & 44.41 & 44.42 \\
$\overline{f_{\mathrm{cu}}}(\mathrm{MPa})$ & & & & 43.87 & & \\
\hline
\end{tabular}

TABLE 2: Physical parameters of test material.

\begin{tabular}{|c|c|c|c|c|}
\hline Material & $\begin{array}{l}\text { Unit weight } \\
\left(\mathrm{KN} / \mathrm{m}^{3}\right)\end{array}$ & $\begin{array}{c}\text { Elastic modulus } \\
(\mathrm{GPa})\end{array}$ & Poisson's ratio & $\begin{array}{c}\text { Mix ratio } \\
\text { (water: cement: sand : gravel) }\end{array}$ \\
\hline $\begin{array}{l}\text { Latticed } \\
\text { concrete }\end{array}$ & 2400 & 20 & 0.2 & $0.44: 1: 1.06: 2.26$ \\
\hline Frame concrete & 2500 & 33 & 0.2 & $0.47: 1: 1.82: 3.87$ \\
\hline НРB300 & 7800 & 210 & 0.3 & - \\
\hline HRB335 & 7800 & 200 & 0.3 & - \\
\hline HRB400 & 7800 & 200 & 0.3 & - \\
\hline
\end{tabular}

those at the base beam were to measure the displacement of the shake table. $2 \times 2$ accelerometers were set at the base beam in both of the $x$ - and $y$-directions in order to measure actual base excitations. Three accelerometers, one in the edge and two in the middle, were arranged on the slab, and the rest of accelerometers were attached to each of walls of structural height $1.5 \mathrm{~m}$. Steel strain gauges were attached to the horizontal and vertical rebar embedded in the walls; concrete strain gauges were attached to the bottom of frame column. Figure 8 depicts the locations of accelerometers, displacement transducers, and strain gauges. The letters "A," "D," and "S" refer to accelerometers, displacement transducers, and strain gauges, respectively. All data were acquired simultaneously at a sampling rate of $200 \mathrm{~Hz}$ on 70 channels.

2.4. Input Motions and Testing Program. The site condition is an important factor in determining the input motion for the dynamic test of structure. Taking site condition into consideration, three strong motion records were chosen as the input motions in the shaking table test: (i) El Centro NS record from the California Imperial Valley earthquake on 18 May 1940, which is specified for site classes III and IV, (ii) Taft EW record from the California Kern County earthquake of 21 July 1952, which is specified for site classes II and III, and (iii) Wolong EW record from the Wenchuan earthquake of 12 May 2008, which is specified for site classes I and II in Chinese code $[21,22]$. Figure 9 shows the acceleration time histories and response spectra of the three input motions. It is inferred that the spectral components of the three input motions is rich enough for the study.

The intensity of the three input motions was controlled by adjusting the maximum displacement amplitude of the shake table, and the three input motions were applied only in $y$-direction. The model structure was tested under 18 cases of input motions with gradually increasing peak ground acceleration (PGA) and 4 cases of input white noises. The maximum testing PGA was $0.30 \mathrm{~g}$ for the input Taft record, $0.30 \mathrm{~g}$ for the input El Centro, and $1.00 \mathrm{~g}$ for the input Wolong record. The test was divided into three consecutive stages. Cases 2 to 10 were applied in the first stage, cases 12 to 16 in the second stage, and cases 18 to 21 in the third stage. To detect the change in the natural frequencies of the structure, white noise scanning was conducted in the $x$-and $y$-directions before and after each stage. The testing cases are listed in Table 3.

\section{Experimental Results and Analysis}

3.1. Testing Observation. Table 4 summarizes the macroscopic phenomena observed at various levels of input motions. At linear elastic stage (PGA $\leq 0.15 \mathrm{~g})$, there were no noticeable structure shaking response and damage observed. Based on the observed response of the model, it is surmised that the structure was in serviceable condition. When input motions are with PGA $=0.2 \mathrm{~g}$, some small cracks were first 

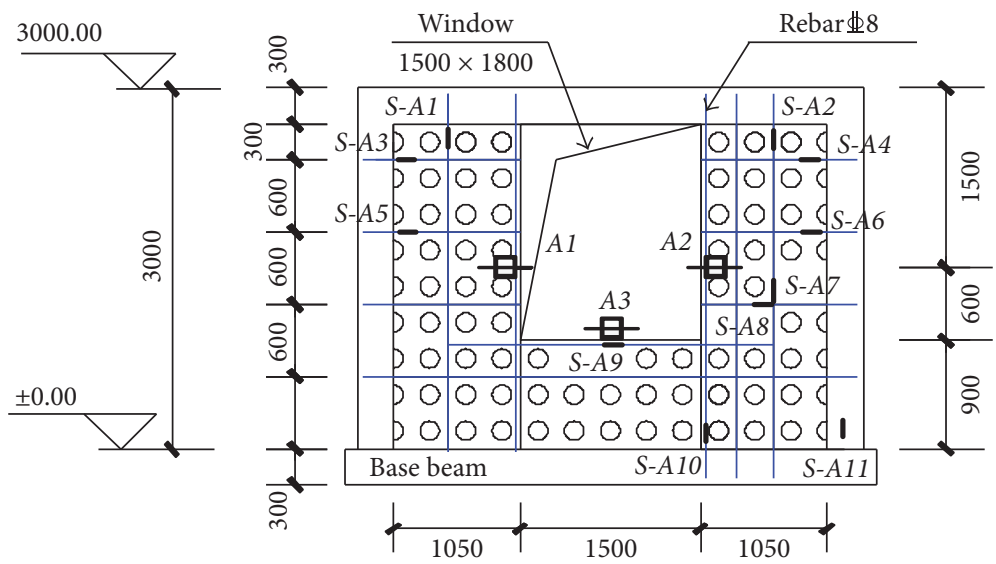

S: strain gauge

E- A: accelerometer in plane

(a)

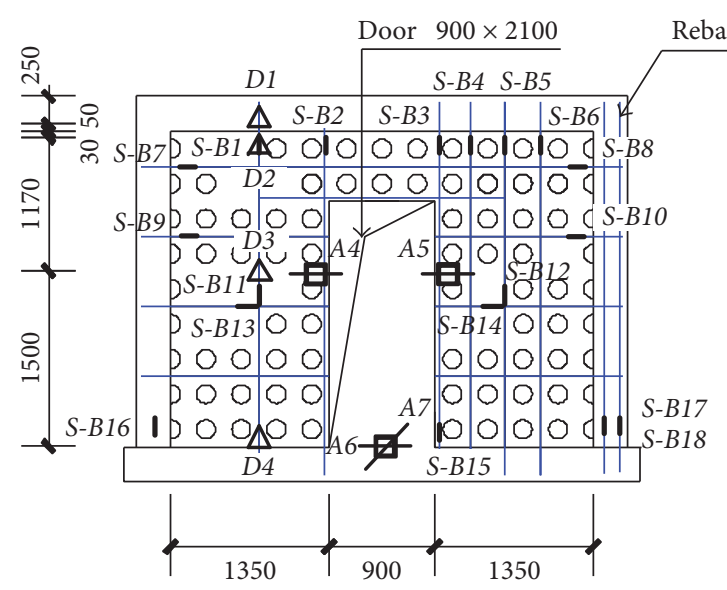

- S: strain gauge
\# A: accelerometer in plane

(b)

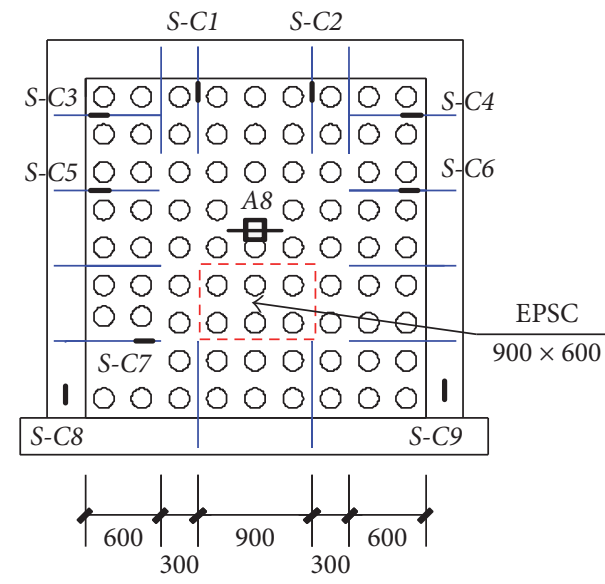

- S: strain gauge

— A: accelerometer in plane

(c)

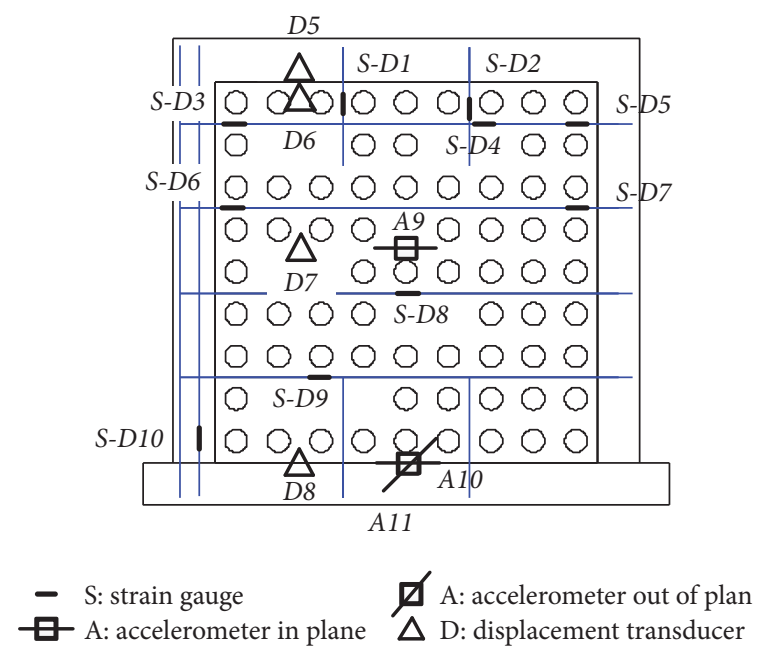

(d)

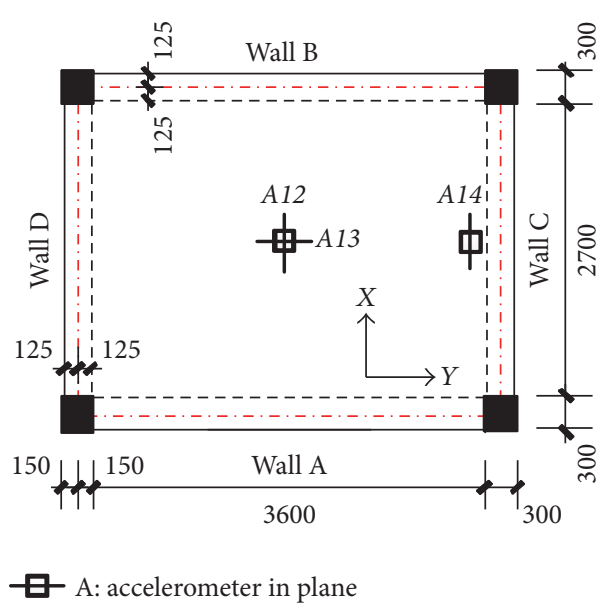

(e)

FIGURE 8: Layout of accelerometers, displacement transducers, and strain gauges (unit: mm): (a) wall A, (b) wall B, (c) wall C, (d) wall D, and (e) slab. 

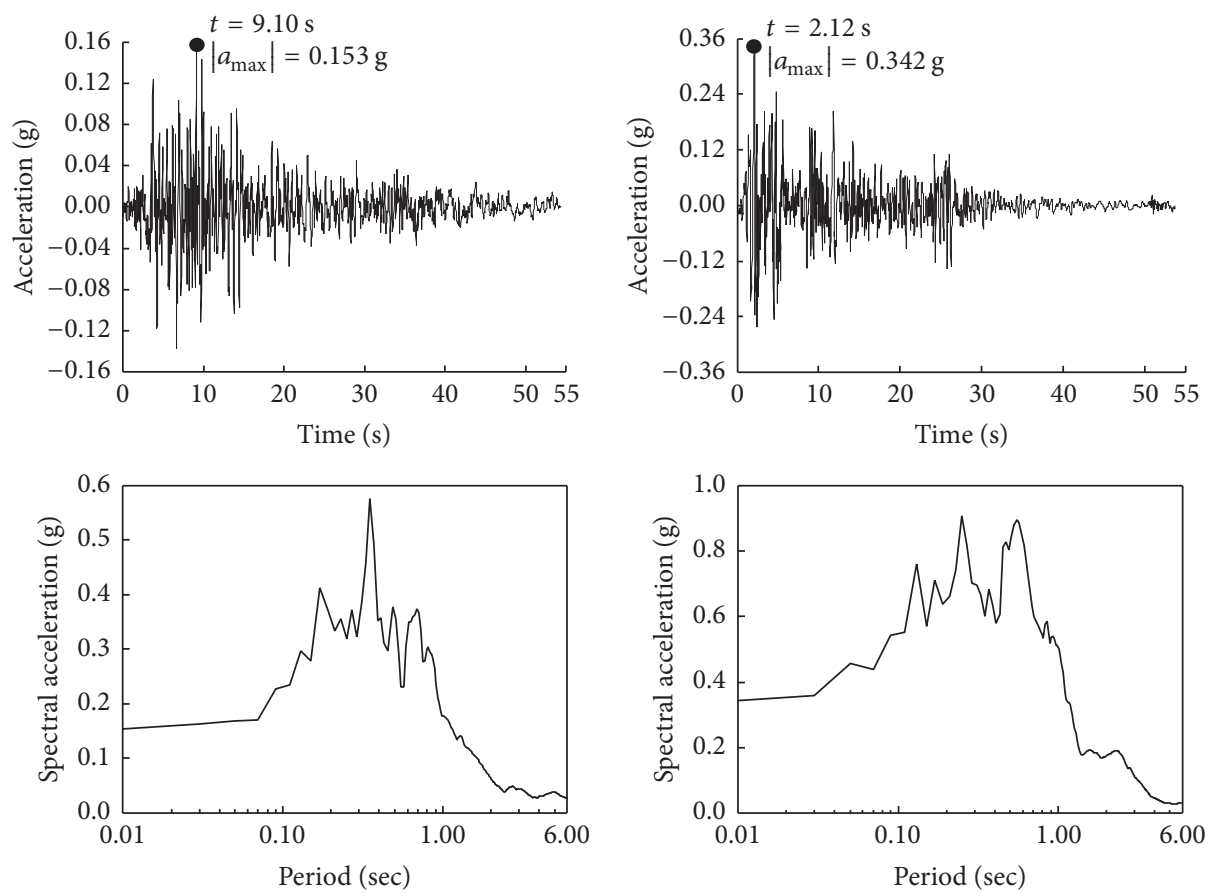

(a)

(b)
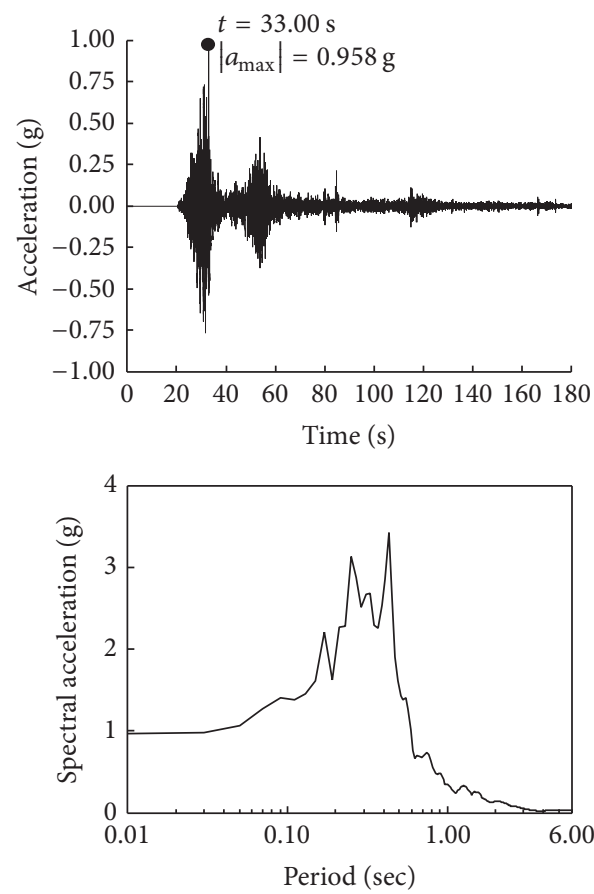

(c)

FIGURE 9: Acceleration time histories and spectral acceleration of the ground motion records: (a) Taft record, (b) El Centro record, and (c) Wolong record (EW).

found at the EPSC in the diagonal and vertical direction. Those cracks were concentrated at the corners of the openings. After the testing of input motions with PGA $=0.30 \mathrm{~g}$, cracks were observed at the wall-frame interfaces. After the testing of Wolong record input with PGA $=0.50 \mathrm{~g}$, horizontal, diagonal, and vertical cracks appeared on the periphery of wall openings (see Figure 10(a)). In failure stage (for the Wolong record input with PGA $=0.78 \mathrm{~g}$ and $1.00 \mathrm{~g}$ ), the model structure vibrated significantly and the cracks in the walls extended and widened. The roof departed from frame. However, there were no spalling of concrete and buckling of main rebar, and also no cracks were found on the surfaces of the RC 


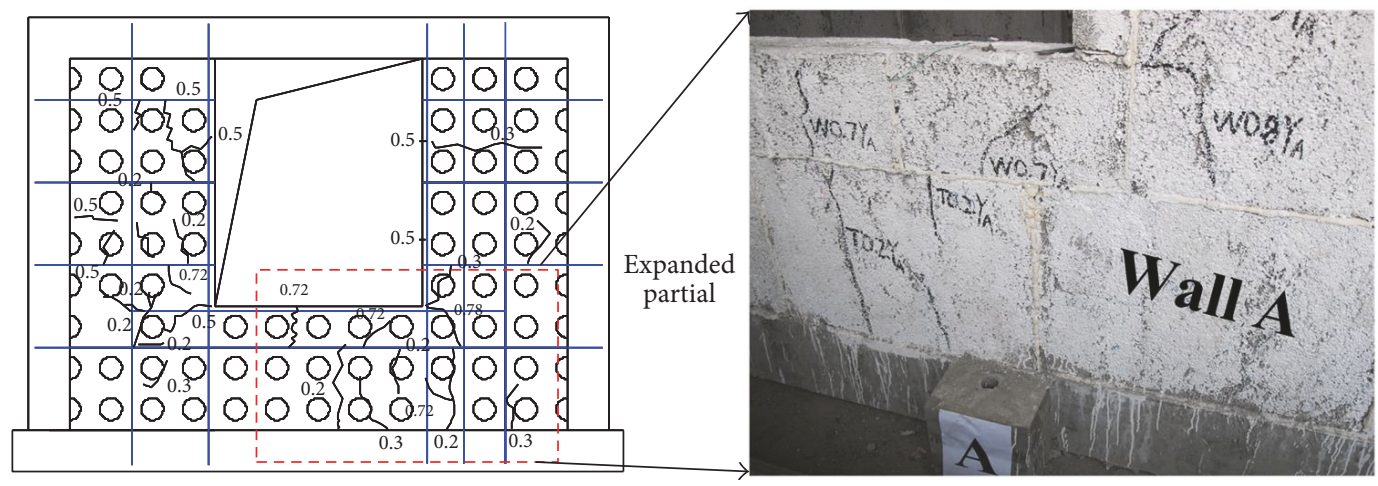

(a)

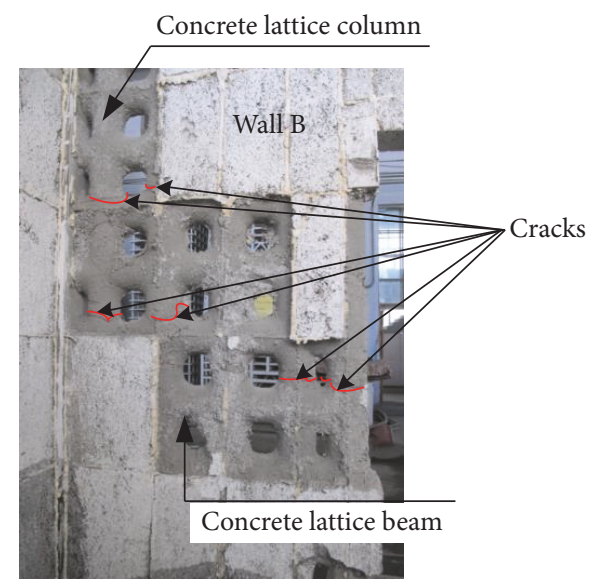

(b)

FIGURE 10: Observed cracks in the model structure: (a) EPSC latticed concrete wall A and (b) EPSC latticed concrete wall B.

frame. It shows that the RC frame was in a state of no damage.

After the tests, removing the EPSC from the walls, the tiny horizontal and circular cracks at the concrete lattice column could be found (see Figure 10(b)). In general, the model was slightly damaged; it means that some of the structural members will have to be repaired.

3.2. Fundamental Frequencies. To identify the fundamental frequencies and modal damping ratios of the tested model, the testing was done under white noise input of PGA = $0.050 \mathrm{~g}$ in the $x$-direction and $y$-direction before and after each stage. The acceleration responses recorded were then processed to obtain the transfer functions [23], from which the fundamental frequency and modal damping ratios were achieved. Table 5 shows the fundamental frequencies and corresponding damping ratios of the model for different stages of test process. The initial fundamental frequency of the test model was $17.04 \mathrm{~Hz}$ in $y$-direction and $14.21 \mathrm{~Hz}$ in $x$-direction. But after the Wolong record input with PGA $=1.00 \mathrm{~g}$, the fundamental frequency decreased to $12.62 \mathrm{~Hz}$ (reduction ratio of $25.9 \%$ ) in $x$-direction and $11.99 \mathrm{~Hz}$ (reduction ratio of $15.6 \%)$ in $y$-direction. Meanwhile, the damping ratio gradually increased from $0.84 \%$ for initial stage to $1.30 \%$ for elastic stage, $1.97 \%$ for crack development stage, and $2.57 \%$ for failure stage. The results indicate that the postearthquake stiffness of the structure decreased, which was possibly due to the infill walls being damaged. Changes of fundamental frequencies and damping ratio agree well with observations. Some cracks appeared around the wall openings after the tests. Compared with the fundamental frequency in $x$-direction, it was smaller in $y$-direction. This is because there were openings on the latticed concrete infill walls in $y$-direction, and the stiffness of the model structure in $y$-direction was smaller than that in $x$-direction.

3.3. Acceleration Responses. Figure 11 shows the acceleration time histories of structural response for different input motions. The in-plane peak acceleration amplification factors ( $a_{\max } / A_{\max }$, where $A_{\max }$ is the peak acceleration of the input motion at base beam and $a_{\max }$ is the peak acceleration of the response motion at infill walls or the slab) along the structural height are shown in Figure 12. Note that as the PGA of input motion increased from $0.10 \mathrm{~g}$ to $0.30 \mathrm{~g}$, the amplification factor increased gradually. The amplification factor increased along the structural height under Wolong record input, and the amplification factor ranged from 1.20 to 1.35 on the slab. However, the amplification factor increased firstly and then decreased along the structural height under El Centro record input, and the amplification factor on the slab was close 
TABLE 3: List of testing cases.

\begin{tabular}{|c|c|c|c|c|c|}
\hline \multirow{2}{*}{ Case } & \multirow{2}{*}{ Input motion } & \multicolumn{2}{|c|}{ PGA $(\mathrm{g})$} & \multirow{2}{*}{$\begin{array}{l}\text { Duration } \\
\quad(\mathrm{s})\end{array}$} & \multirow{2}{*}{ Remark } \\
\hline & & Design value & Measured value & & \\
\hline 1 & White noise & 0.05 & 0.05 & 180 & $\begin{array}{c}\text { Frequency } \\
\text { measurement }\end{array}$ \\
\hline 2 & Taft & 0.10 & 0.10 & 54 & \multirow{9}{*}{$\begin{array}{c}\text { First stage } \\
\text { (linear elastic) }\end{array}$} \\
\hline 3 & El Centro & 0.10 & 0.10 & 54 & \\
\hline 4 & Wolong & 0.10 & 0.09 & 180 & \\
\hline 5 & Taft & 0.15 & 0.15 & 54 & \\
\hline 6 & El Centro & 0.15 & 0.15 & 54 & \\
\hline 7 & Wolong & 0.15 & 0.14 & 180 & \\
\hline 8 & Taft & 0.20 & 0.20 & 54 & \\
\hline 9 & El Centro & 0.20 & 0.20 & 54 & \\
\hline 10 & Wolong & 0.20 & 0.19 & 180 & \\
\hline 11 & White noise & 0.05 & 0.05 & 180 & $\begin{array}{c}\text { Frequency } \\
\text { measurement }\end{array}$ \\
\hline 12 & Taft & 0.30 & 0.30 & 54 & \multirow{5}{*}{$\begin{array}{c}\text { Second stage } \\
\text { (crack development) }\end{array}$} \\
\hline 13 & El Centro & 0.30 & 0.30 & 54 & \\
\hline 14 & Wolong & 0.30 & 0.30 & 180 & \\
\hline 15 & Wolong & 0.40 & 0.40 & 180 & \\
\hline 16 & Wolong & 0.50 & 0.50 & 180 & \\
\hline 17 & White noise & 0.05 & 0.05 & 180 & $\begin{array}{c}\text { Frequency } \\
\text { measurement }\end{array}$ \\
\hline 18 & Wolong & 0.60 & 0.60 & 180 & \multirow{4}{*}{$\begin{array}{l}\text { Third stage } \\
\text { (failure) }\end{array}$} \\
\hline 19 & Wolong & 0.700 & 0.72 & 180 & \\
\hline 20 & Wolong & 0.80 & 0.78 & 180 & \\
\hline 21 & Wolong & 1.00 & 1.00 & 180 & \\
\hline 22 & White noise & 0.05 & 0.05 & 180 & $\begin{array}{c}\text { Frequency } \\
\text { measurement }\end{array}$ \\
\hline
\end{tabular}

TABLE 4: Macroscopic phenomena of structure.

\begin{tabular}{lcc}
\hline Stage & Observation and type of damage & Condition \\
\hline Elastic & $\begin{array}{c}\text { No noticeable shaking and some barely } \\
\text { noticeable small cracks }\end{array}$ & Serviceable condition \\
Crack development & $\begin{array}{c}\text { Observable vibrations and cracks at the EPSC } \\
\text { appeared in the horizontal, diagonal, and } \\
\text { vertical direction }\end{array}$ & Serviceable condition \\
Failure & $\begin{array}{c}\text { Significant vibration, cracks extended wider } \\
\text { and deeper at the EPSC, and the roof departed } \\
\text { from frame }\end{array}$ & Slightly damaged and requiring repair \\
\hline
\end{tabular}

TABLE 5: Fundamental frequency and damping ratio of the model.

\begin{tabular}{lccc}
\hline Stage & \multicolumn{2}{c}{ Fundamental frequency $(\mathrm{Hz})$} & Damping ratio (\%) \\
\hline Initial & $x$-direction & $y$-direction & 0.84 \\
Elastic & 17.04 & 14.21 & 1.30 \\
Crack development & 15.63 & 13.00 & 1.97 \\
Failure & 13.33 & 12.61 & 2.57 \\
\hline
\end{tabular}



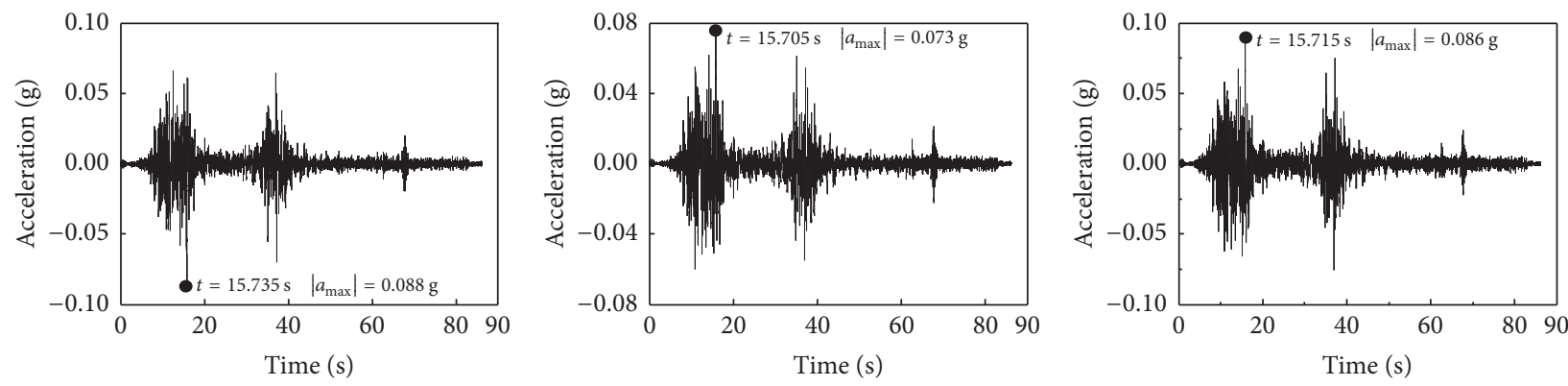

— Wolong $0.09 \mathrm{~g} \mathrm{~A} 2$

— Wolong $0.09 \mathrm{~g} \mathrm{A6}$

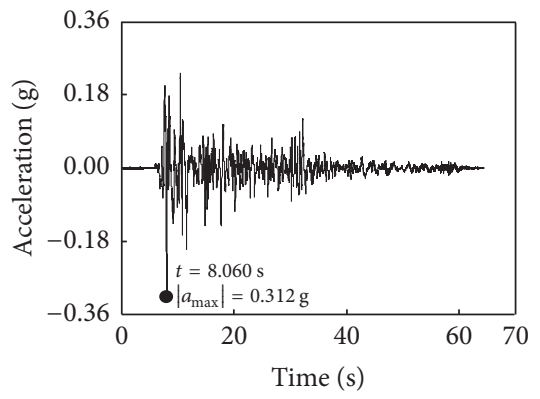

— El Centro $0.30 \mathrm{~g} \mathrm{~A} 2$

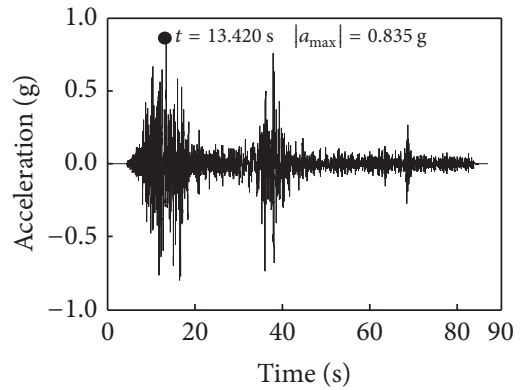

— Wolong $0.72 \mathrm{~g} \mathrm{~A} 2$
— El Centro $0.30 \mathrm{~g} \mathrm{~A} 6$

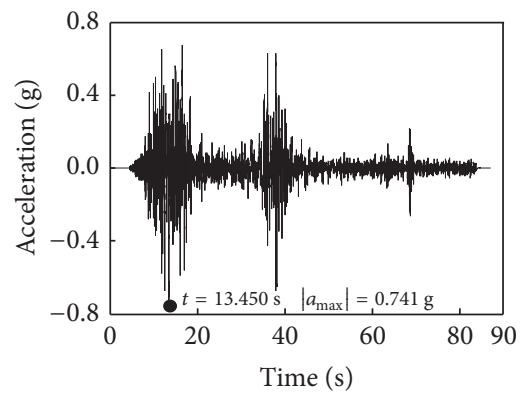

— Wolong $0.72 \mathrm{~g} \mathrm{~A} 6$

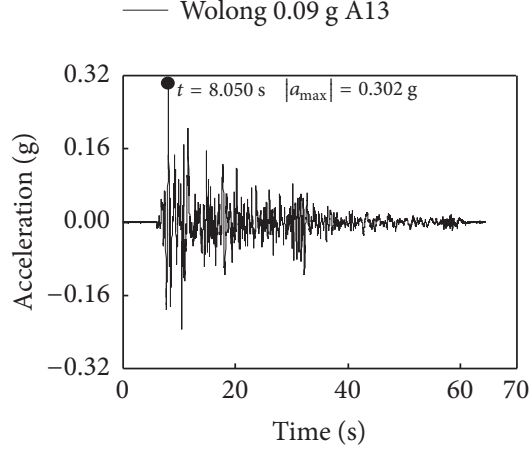

— El Centro $0.30 \mathrm{~g} \mathrm{~A} 13$

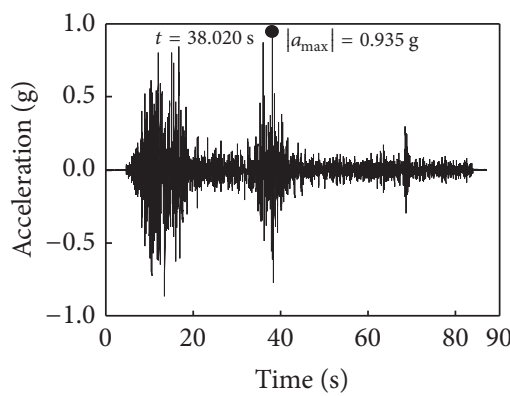

— Wolong $0.72 \mathrm{~g} \mathrm{~A} 13$

FIGURE 11: Acceleration time histories of the model structure under different input motions.

to 1.00 . The results show that the spectral characteristics of the input motion had significant effect on the dynamic response of the model. The amplification factors induced by the Wolong record input were greater than those by the El Centro record input (e.g., $\mathrm{PGA}=0.3 \mathrm{~g}$ ). It indicates that the seismic response of the model structure was more sensitive to the ground motions with long duration for the same PGA. When PGA was greater than $0.30 \mathrm{~g}$, the amplification factor decreased slightly as a result of the stiffness degradation of the model structure.

The out-of-plane peak acceleration amplification factors along the structural height are shown in Figure 13. Note that the amplification factor increased firstly and then decreased along the structural height for input motions with PGA $=0.15 \mathrm{~g}$. However, for input motions with $\mathrm{PGA}=0.30 \mathrm{~g}$ and above, the amplification factor approximately increased along the structural height. The amplification factor induced by Wolong record input was greater than those by Taft or
El Centro record input. This agrees well with the in-plane acceleration response.

Figure 14 presents the response spectral acceleration ratio $\left(S_{\mathrm{Ai}} / S_{\mathrm{A}}\right.$, where $S_{\mathrm{A}}$ is the spectral acceleration of the input motion at the base beam and $S_{\mathrm{Ai}}$ is the spectral acceleration of the structural response motion at the infill walls or the slab) under different input motions. Note that the spectral acceleration ratio increases slightly and then decreases with the increase of input PGA from $0.09 \mathrm{~g}$ to $0.30 \mathrm{~g}$ and $0.72 \mathrm{~g}$ under Wolong record input. From Figures 14(a), 14(c), and $14(\mathrm{~d})$, it is clear that the peak dominant period moves toward longer periods with the increase of PGA of the input motion. The results indicate that some of the structural members might be damaged under strong input motions and the stiffness of the model structure also decreased. From Figures 14(b) and 14(c), the spectral acceleration ratios under Wolong record input are larger than those under Taft record input with the same $\mathrm{PGA}=0.30 \mathrm{~g}$. The spectral acceleration ratio 


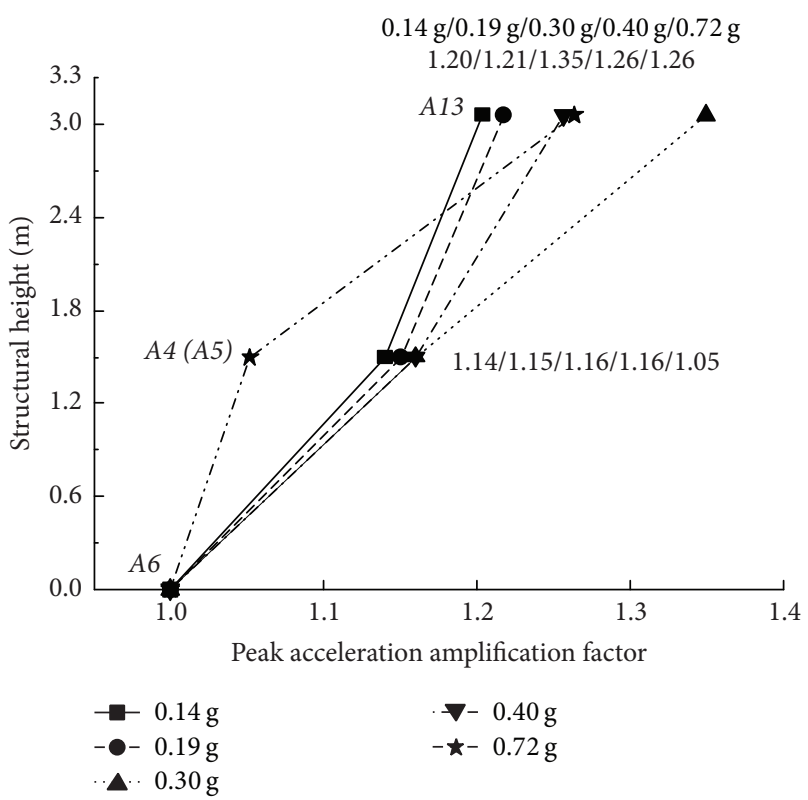

(a)

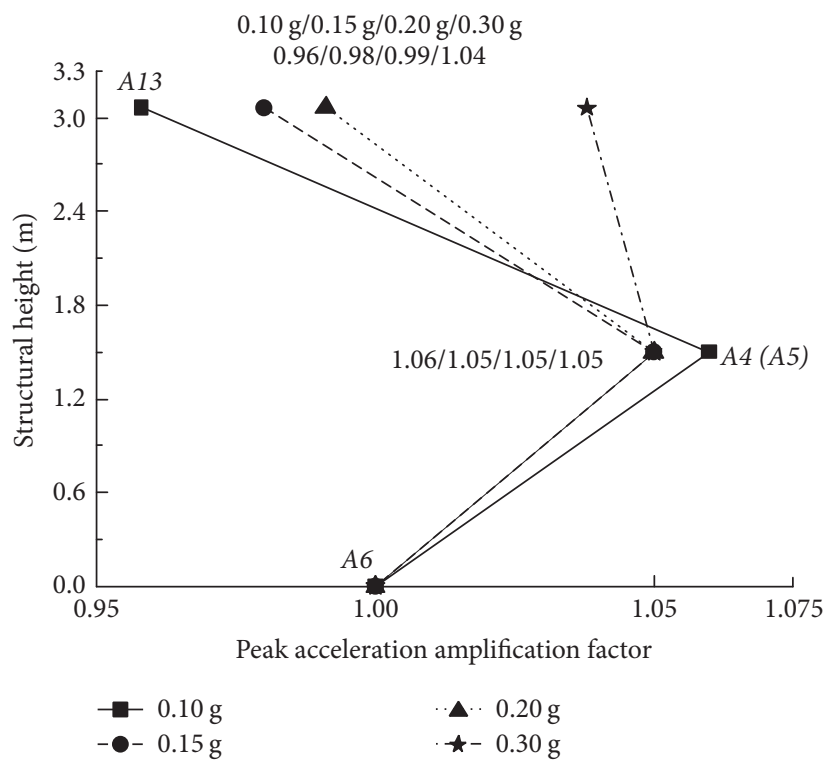

(b)

Figure 12: Peak acceleration amplification factors of the model structure: (a) under Wolong record input and (b) under El Centro record input.

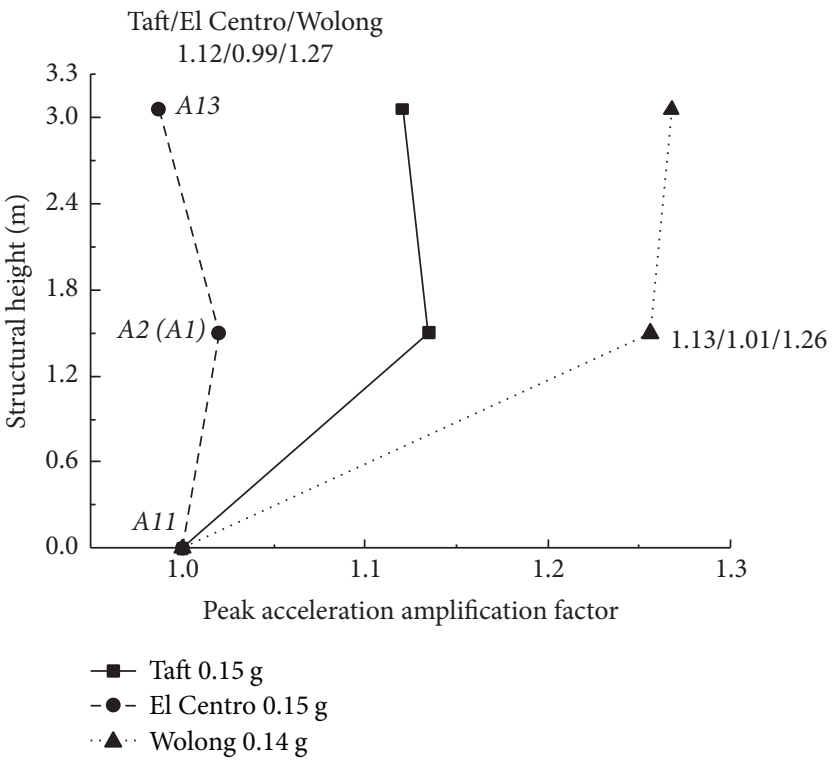

(a)

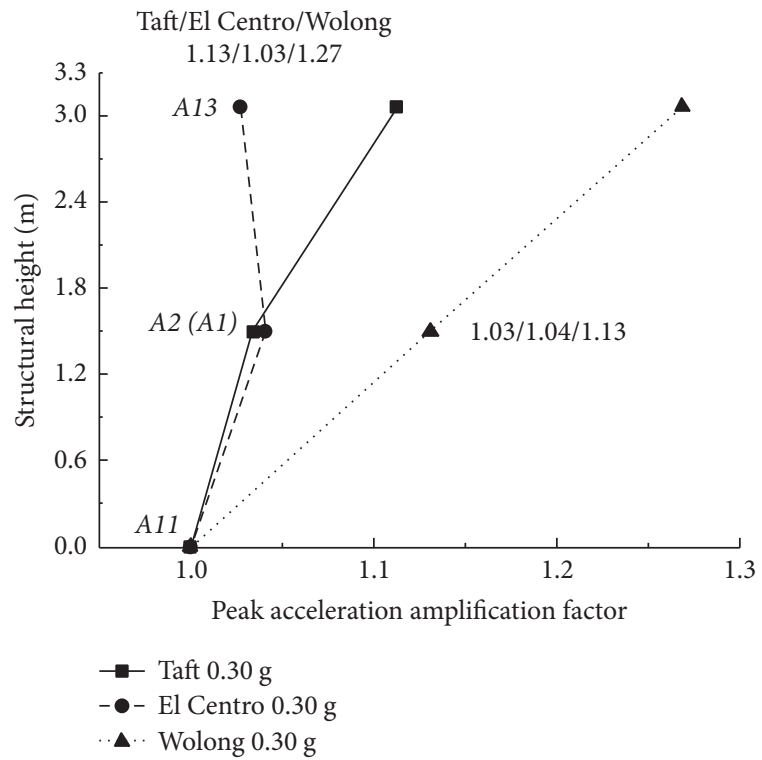

(b)

FIGURE 13: Comparison of out-of-plane peak acceleration amplification factors of the model for different input motions: (a) input motion with $\mathrm{PGA}=0.15 \mathrm{~g}$ and $(\mathrm{b})$ input motion with $\mathrm{PGA}=0.3 \mathrm{~g}$.

has positive correlation with the structural height, which agrees well with the acceleration response. It is clear that the spectral acceleration ratios are almost larger than 1 , and the curve shapes at different points are approximately similar, which means that the RC frame with infill walls exhibited excellent integrity.
3.4. Displacement Responses. Figure 15 shows the displacement time history of structural response at the frame beam (point D5) and the top of infill wall (point D6) under the Taft record input with PGA $=0.10 \mathrm{~g}$, El Centro record input with PGA $=0.30 \mathrm{~g}$, and Wolong record input with PGA $=1.00 \mathrm{~g}$. The residual displacement was minimal for input 

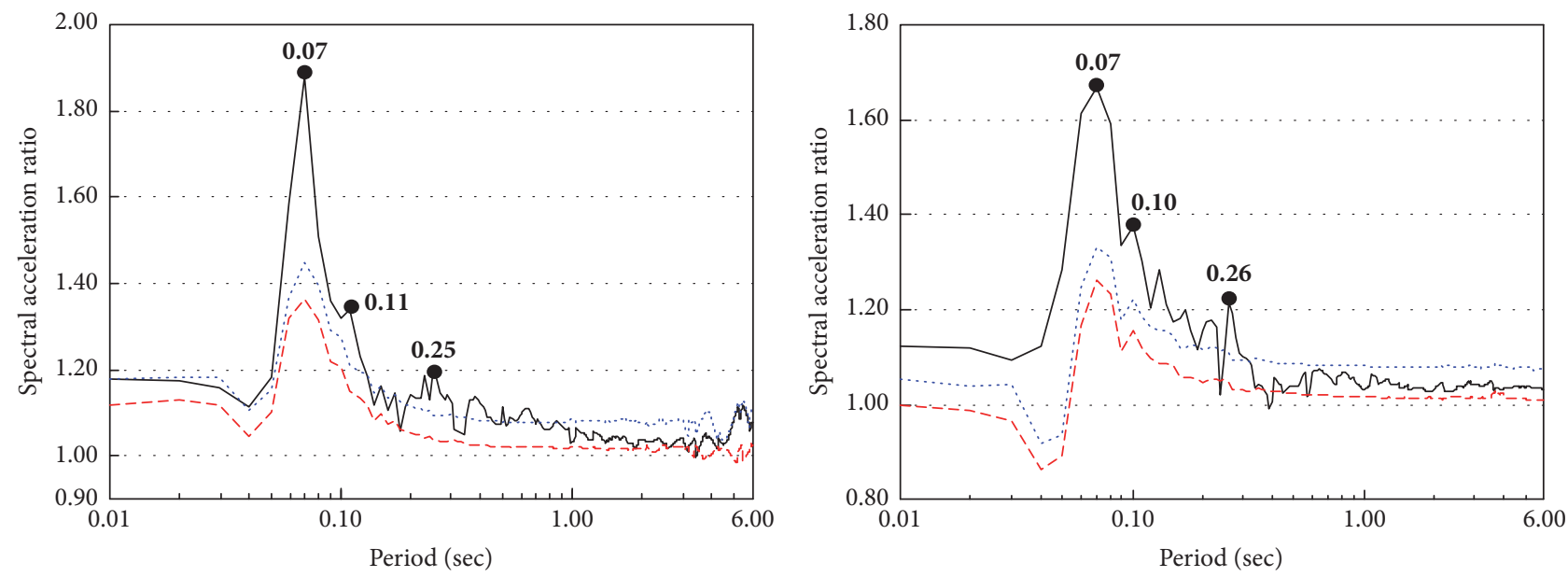

Wolong $0.09 \mathrm{~g}$

Taft $0.30 \mathrm{~g}$

$-\mathrm{A} 13$

$---\mathrm{A} 5$

--- A5

...... A4

(a)
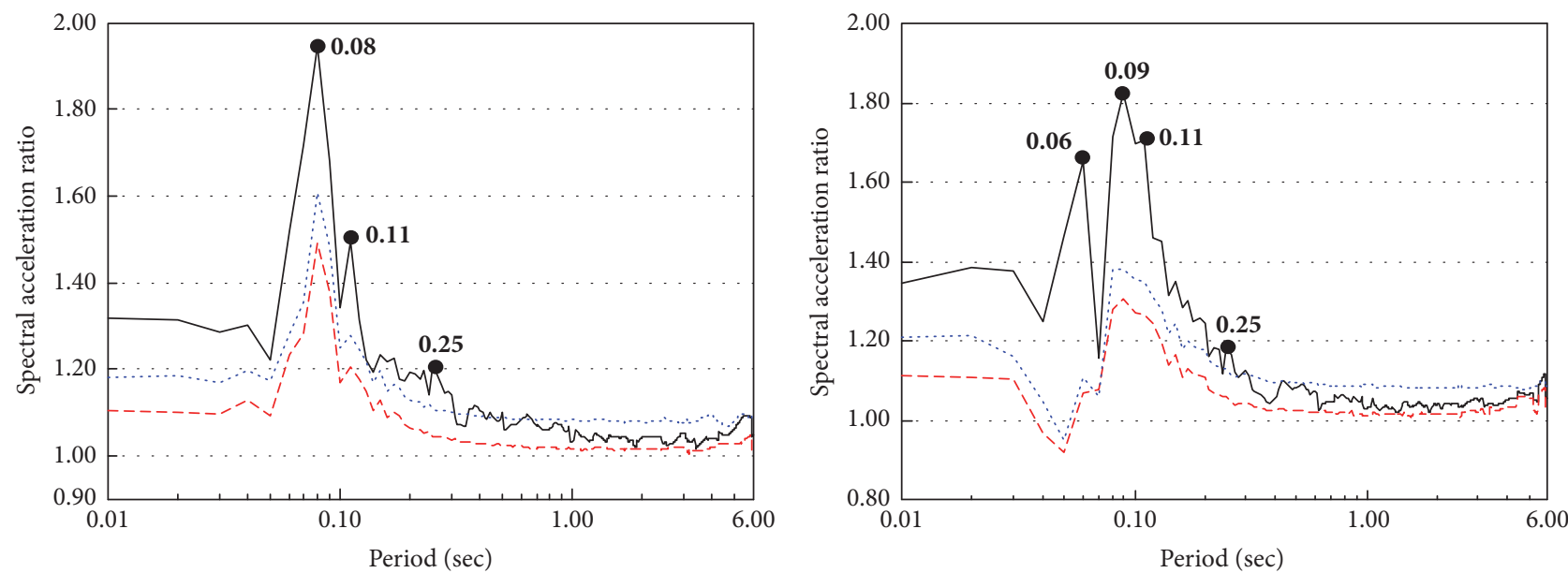

Wolong $0.30 \mathrm{~g}$

- A13

-- A5

… A4

(c)

(d)

FIGURE 14: Spectral acceleration ratio of the structural responses under different input motions: (a) case 4, (b) case 12, (c) case 14, and (d) case 19.

motion with PGA $=0.30 \mathrm{~g}$. Table 6 shows the maximum displacement of structural responses along the structural height. The maximum displacement of slab response was 69.07 $\mathrm{mm}$ which was recorded at D5 under the Wolong record input with $\mathrm{PGA}=0.72 \mathrm{~g}$. The maximum displacement at D6 (on the top of wall) was smaller than that at D7 (in the middle of wall). The result indicates that the vertical and horizontal rebar, embedded in the top of latticed concrete infill wall and their surrounding RC frames, could effectively restrain the wall displacement.

Figure 16 presents the relative displacements of measuring points (D5-D8) along the structural height. It shows that the deformation shape of RC frame with latticed concrete infill wall was basically shearing type. The maximum displacements of measuring points D5 and D6 exhibited remarkable difference. It suggests that there was relative displacement between the latticed concrete infill wall and RC frame beam under earthquake excitations, and the frame beam-latticed concrete infill wall could be equivalent to a hinge joint. The maximum story drift was about $5.0 \mathrm{~mm}$ under the Wolong record input with PGA $=1.00 \mathrm{~g}$. Meanwhile, the interstory drift reached $1 / 513$, which is close to the limit value of the elastic interstory drift of RC frame structure $1 / 550$ (GB 50011-2010). It means that the model structure 

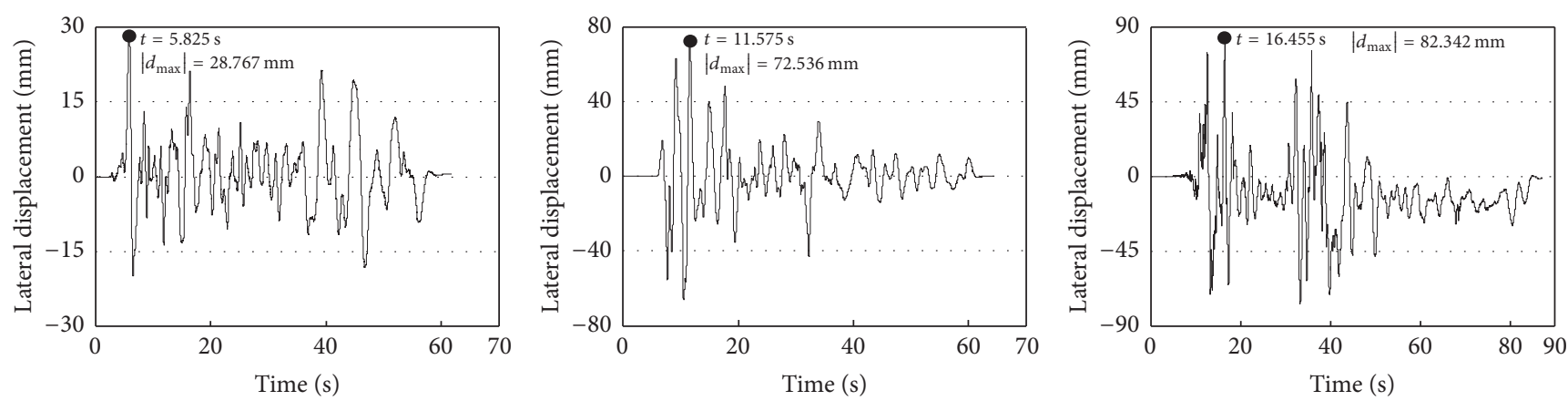

— Taft $0.10 \mathrm{~g}$ D5

_ El Centro $0.30 \mathrm{~g}$ D5
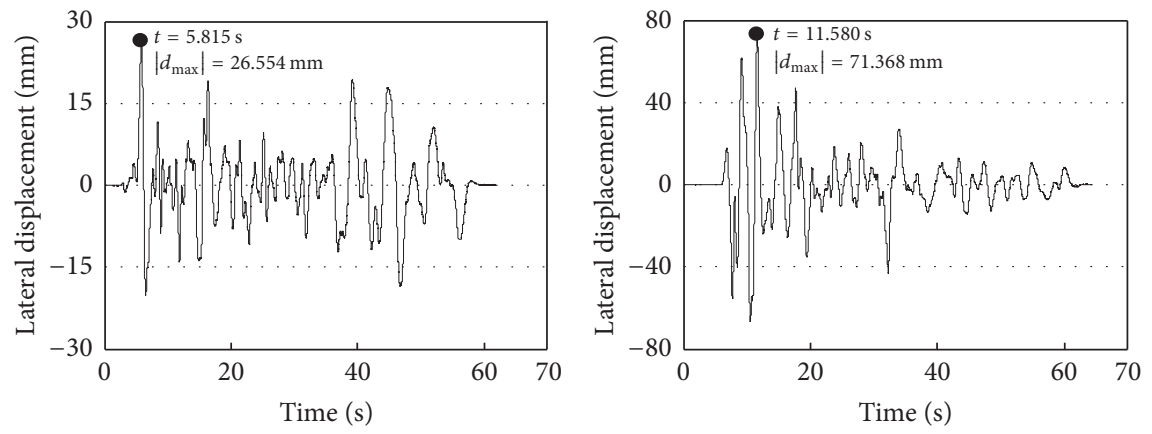

— Wolong $1.00 \mathrm{~g}$ D5

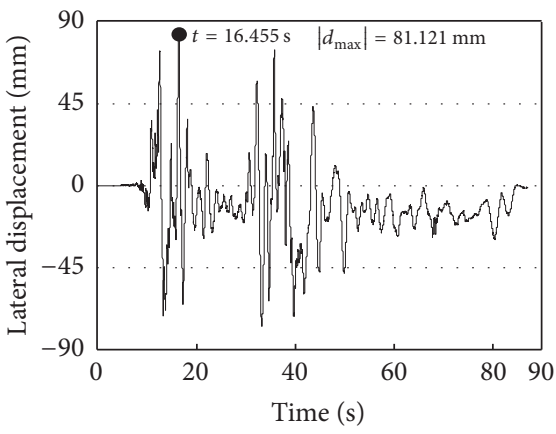

— Taft $0.10 \mathrm{~g}$ D6

— El Centro $0.30 \mathrm{~g}$ D6

— Wolong $1.00 \mathrm{~g} \mathrm{D6}$

FIGURE 15: Displacement time histories of structural response at the frame beam and the top of infill wall under different input motions (unit: $\mathrm{mm})$.

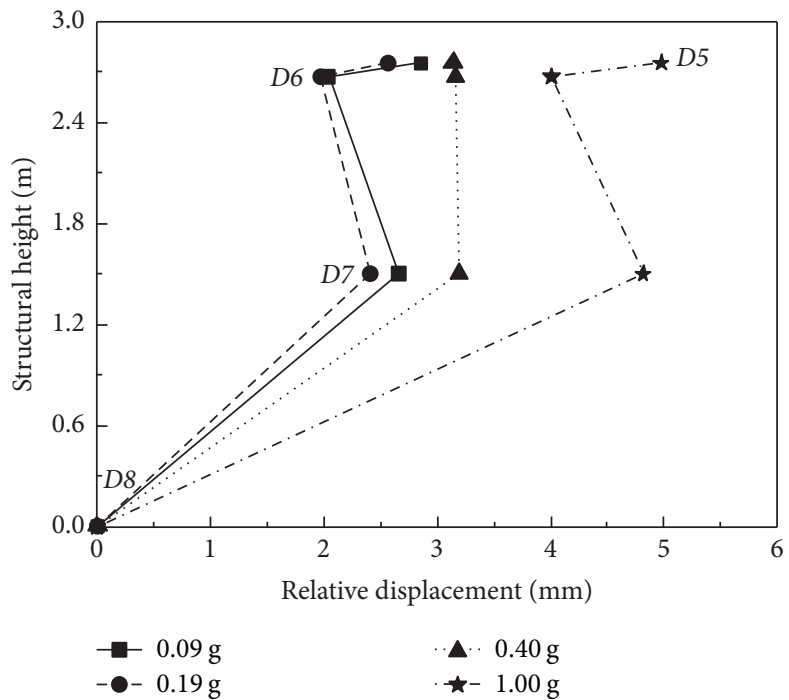

FIGURE 16: Relative displacement along structural height under Wolong records.

TABLE 6: Displacement response of the model for different input motions (unit: $\mathrm{mm}$ ).

\begin{tabular}{|c|c|c|c|c|c|c|c|c|c|c|}
\hline \multirow{3}{*}{ Sensor } & \multicolumn{10}{|c|}{ Input motion } \\
\hline & \multicolumn{3}{|c|}{ Taft } & \multicolumn{3}{|c|}{ El Centro } & \multicolumn{4}{|c|}{ Wolong } \\
\hline & $0.10 \mathrm{~g}$ & $0.20 \mathrm{~g}$ & $0.30 \mathrm{~g}$ & $0.10 \mathrm{~g}$ & $0.20 \mathrm{~g}$ & $0.30 \mathrm{~g}$ & $0.14 \mathrm{~g}$ & $0.30 \mathrm{~g}$ & $0.50 \mathrm{~g}$ & $0.72 \mathrm{~g}$ \\
\hline D5 & 28.77 & 56.61 & 72.40 & 32.38 & 56.88 & 72.54 & 14.47 & 33.59 & 49.09 & 69.07 \\
\hline D6 & 26.56 & 55.11 & 71.20 & 30.11 & 55.26 & 71.37 & 13.44 & 32.16 & 47.27 & 67.86 \\
\hline D7 & 27.52 & 55.76 & 71.81 & 31.13 & 55.93 & 71.76 & 13.75 & 32.29 & 47.62 & 67.95 \\
\hline D8 & 26.81 & 54.30 & 70.11 & 29.86 & 53.80 & 69.87 & 13.45 & 31.08 & 46.01 & 65.81 \\
\hline
\end{tabular}




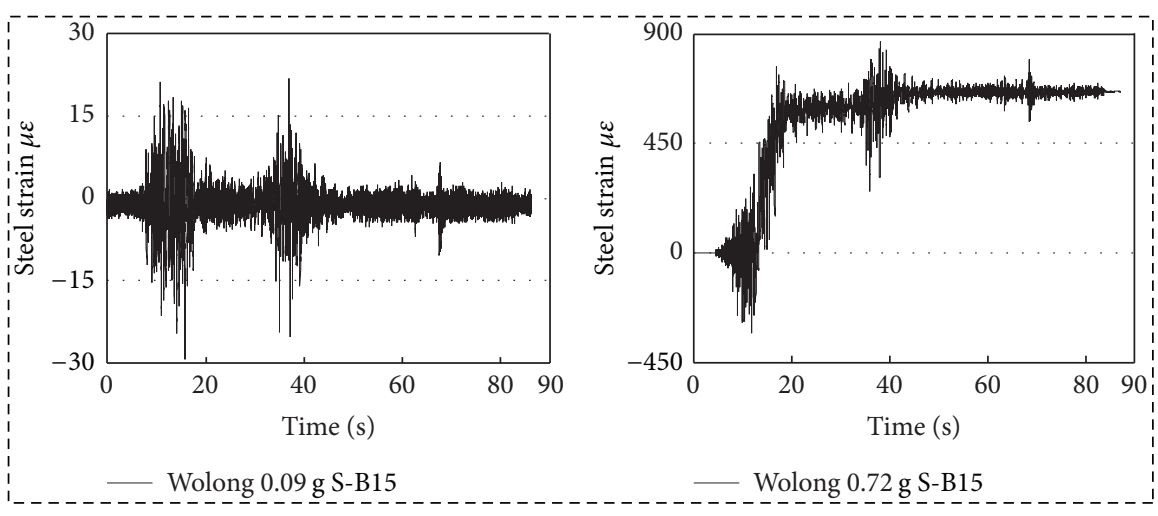

(a)

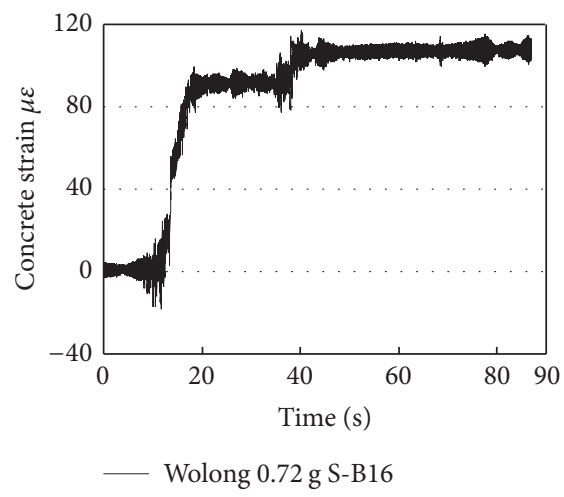

(b)

FIGURE 17: Strain time histories of the rebar and concrete under Wolong record input: (a) rebar and (b) concrete.

TABLE 7: Peak tensile strain of latticed concrete infill walls $(\mu \varepsilon)$.

\begin{tabular}{|c|c|c|c|c|c|c|c|c|c|}
\hline \multirow{2}{*}{ Input motion } & \multirow{2}{*}{ Strain gauge } & \multicolumn{7}{|c|}{ PGA (g) } & \multirow{2}{*}{ Rebar spacing $(\mathrm{mm})$} \\
\hline & & 0.09 & 0.19 & 0.30 & 0.40 & 0.60 & 0.72 & 0.78 & \\
\hline \multirow{4}{*}{ Wolong } & S-A1 & 6.5 & 12.1 & 68.8 & 109.5 & 317.9 & 507.2 & 633.4 & 600 \\
\hline & S-A2 & 5.3 & 9.6 & 13.7 & 35.0 & 51.1 & 64.5 & 73.4 & 300 \\
\hline & S-B1 & 121.1 & 392.4 & 554.7 & 980.3 & 1179.2 & 1411.5 & 1531.6 & 600 \\
\hline & S-B5 & 14.4 & 31.4 & 62.6 & 97.7 & 136.4 & 167.8 & 154.6 & 300 \\
\hline
\end{tabular}

might remain in serviceable condition after Wolong record input with $\mathrm{PGA}=1.00 \mathrm{~g}$. The interstory drift was minimal, which demonstrated the EPSC latticed concrete infill wall with higher stiffness. In general, the infill wall could bear larger shear force and significantly reduce the story drift of the model structure, and the walls could be equivalent to the $\mathrm{RC}$ shear wall.

3.5. Strain Responses. Figure 17 shows the strain time histories of the rebar in the bottom of infill wall and the concrete on the frame column under Wolong record input. It is clear that residual strains were evident under Wolong record input with PGA $=0.72 \mathrm{~g}$. The strain response of the rebar $(900 \mu \varepsilon)$ was much larger than that of the concrete $(120 \mu \varepsilon)$ for the same PGA $=0.72 \mathrm{~g}$, which means that the infill walls could effectively bear the internal forces (shear force and bending moment).

The distribution of peak tensile strains on the latticed concrete infill wall A and wall B is shown in Figure 18. The tensile strain in the infill walls varied significantly, which exhibited remarkable spatial effect. This might be caused by the openings of the walls and spacing of the steel rebar.

As shown in Figures 8 and 18, the spacing of vertical steel rebar is $600 \mathrm{~mm}$ on the left side of the opening and $300 \mathrm{~mm}$ on the right side. Comparing of the strain gauges measuring at points S-A1 and S-A2, S-B1, and S-B5, respectively, the peak tensile strains on the left side of the opening (S-A1 and S-B1) were larger than that on right side (S-A2 and S-B5), as listed in Table 7. This indicates that the smaller the rebar spacing, the smaller the tensile strain measured, and the peak tensile strain had positive correlation with the steel rebar spacing.
Meanwhile, it is observed that the amount and width of cracks on the left side of the openings were significantly more than those on the right side, which means that vertical rebar embedded into latticed concrete infill walls could effectively delay the cracks appearing and restrain the cracks extending. Hence, the ductility of the infill walls could be enhanced.

Figure 19 plots the distribution of peak tensile strains on the latticed concrete infill wall $\mathrm{A}$ and wall $\mathrm{B}$ under Wolong record input. Before test cases of PGA $=0.3 \mathrm{~g}$, the peak tensile strains of most measuring points were less than $100 \mu \varepsilon$. With the increased of PGA, the internal forces and deformations of model structure increased gradually, and the initial cracks appeared when concrete tensile strain reaches ultimate tensile strain. During the failure stage, the rebar tensile strain increased significantly, and the peak tensile strain at point S-B12 reached to $1077.8 \mu \varepsilon\left(53.89 \% \varepsilon_{y k}\right)$, where $\varepsilon_{y k}$ is the yield strain.

From Figure 19(a), the peak tensile strains in the bottom of the latticed concrete infill wall A (point S-A10) and wall $B$ (point S-B15) were larger than those in the middle of wall $A$ and wall $B$. The experimental results show that the failure modes of latticed concrete infill walls with the heightwidth ratio of 2.57 and 1.57 were bending shear mode when subjected to earthquake excitation.

From Figure 19(b), the maximum concrete tensile strain was $120.0 \mu \varepsilon$ (measuring point S-B16) under Wolong record input with $\mathrm{PGA}=0.78 \mathrm{~g}$. Because the input motions was only applied in the $y$-direction, the maximum measuring points S-C8 and S-C9 (out-of-plane) were just $28.4 \mu \varepsilon$ and $28.9 \mu \varepsilon$, respectively, which were smaller than that of the measuring points S-A11 and S-B16 (in-plane). According to the code for 


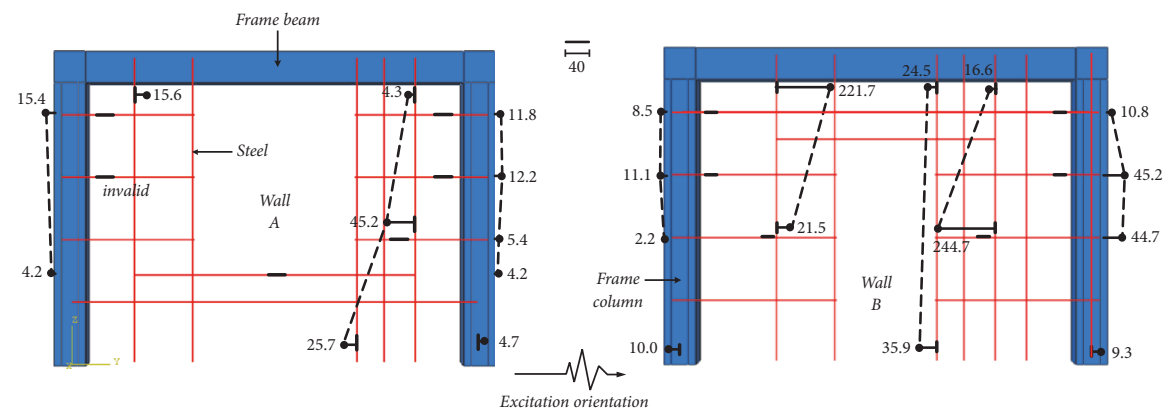

(a)
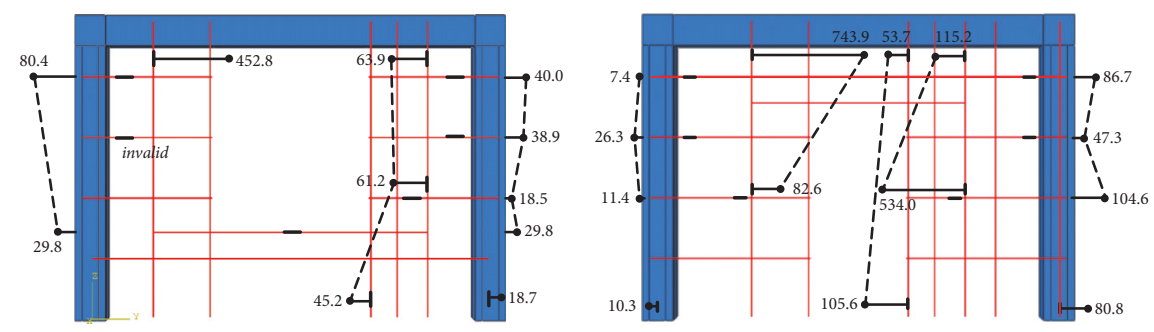

(b)
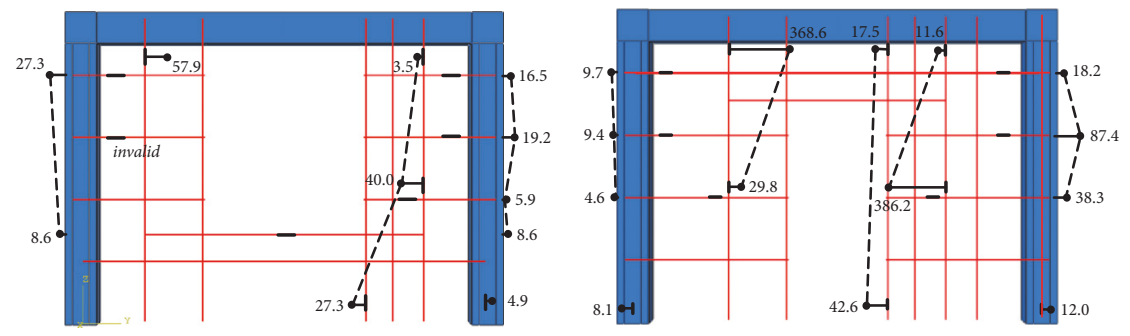

(c)
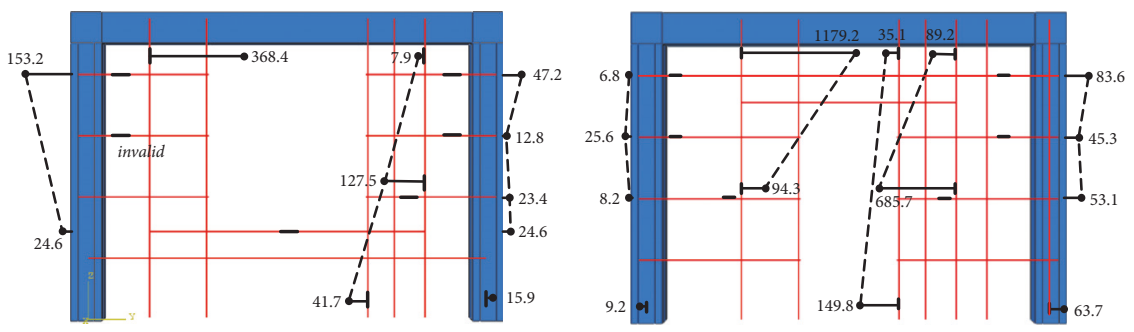

(d)

Figure 18: Distribution of the peak tensile strain under different input motions (unit: $\mu \varepsilon$ ): (a) Taft $0.1 \mathrm{~g}$, (b) Taft $0.3 \mathrm{~g}$, (c) El Centro $0.1 \mathrm{~g}$, and (d) El Centro $0.3 \mathrm{~g}$.

design of concrete structures in China GB 50011-2010, the concrete ultimate tensile strain was approximately $150 \mu \varepsilon$. The results indicate that some barely noticeable small cracks or no cracks would be found on the surface of the RC frame. After each case of the input motions, there was no spalling of concrete, and no noticeable cracks were found on the surface of the RC frame column around the concrete strain gauges. The experimental observation agrees well with the concrete strain measurements. This experimental result shows that $\mathrm{RC}$ frame with EPSC latticed concrete infill wall has a good seismic performance.
3.6. Base Shear. In dynamics of structures, the equation of motion for linearly elastic single-degree-of-freedom (SDOF) system at the seismic excitation can be written in the form of

$$
m \ddot{x}(t)+c \dot{x}(t)+k x(t)=-m \ddot{x}_{g}(t),
$$

where $m, c$, and $k$ denote the mass, damping constant, and stiffness of the structural system; $\ddot{x}(t), \dot{x}(t)$, and $x(t)$ is the acceleration, velocity, and displacement of system; $\ddot{x}_{g}(t)$ is the ground acceleration. 


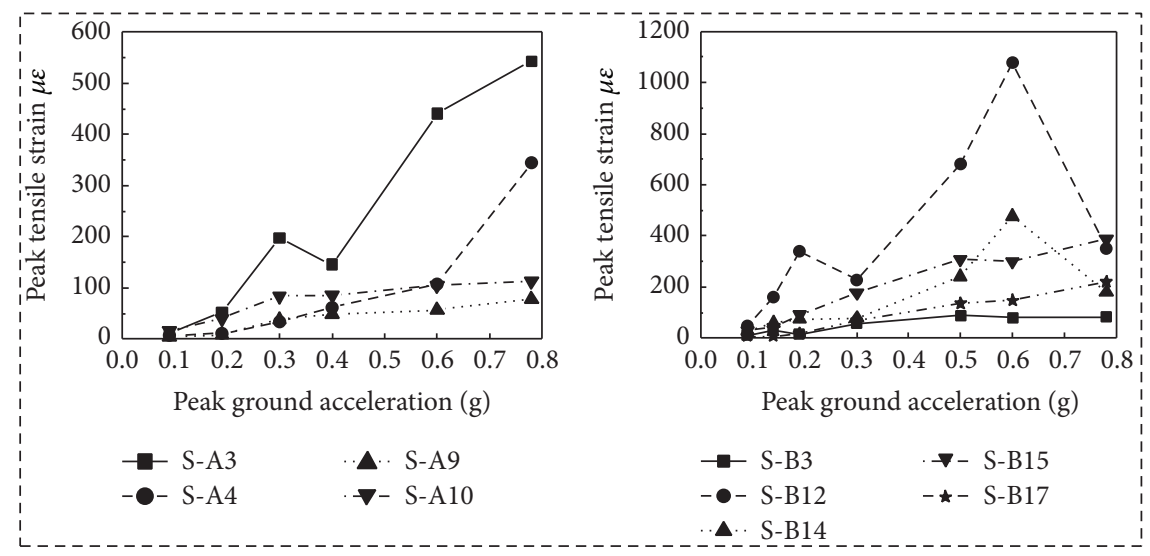

(a)

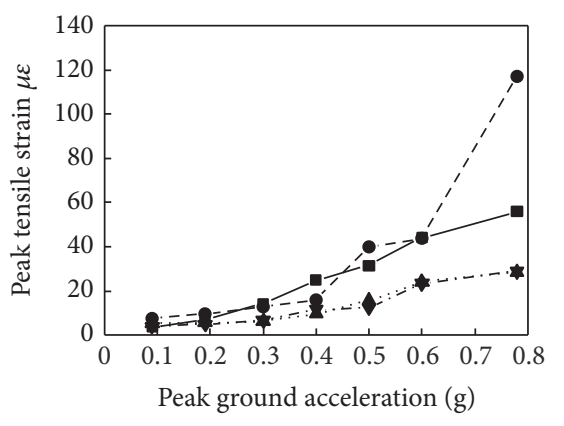

$\rightarrow-$ S-A11 a. S-C8

-๑- S-B16

$\boldsymbol{\nabla}-\mathrm{S}-\mathrm{C} 9$

(b)

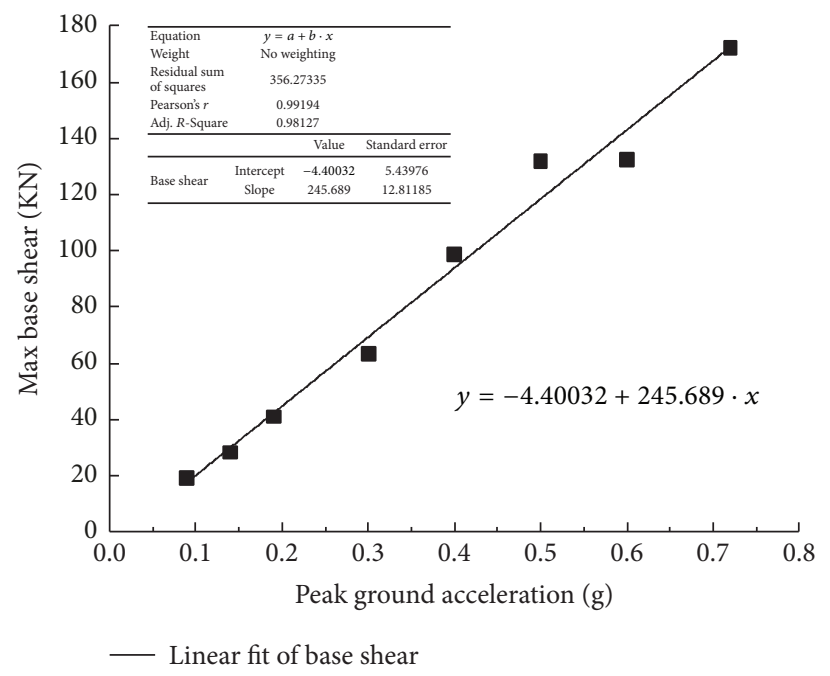

FIGURE 20: The relationship between max base shear and PGA under Wolong record input.

Usually the inertial force as a kind of equivalent force reflected the seismic impact on the structural system, the seismic action can be written as follows:

$$
F(t)=-m\left[\ddot{x}(t)+\ddot{x}_{g}(t)\right] .
$$

Then the maximum seismic action can be conveniently expressed when subjected to earthquake:

$$
F=m\left|\ddot{x}(t)+\ddot{x}_{g}(t)\right|_{\max }=m S_{a}
$$

In this equation, $S_{a}$ denotes the maximum absolute acceleration response.

Meanwhile, the maximum shear $V$ acting on the SDOF system can be written as follows:

$$
V=k|x(t)|_{\max }=k S_{d}
$$

where $S_{d}$ represents the maximum relative displacement response.

Clearly, since the maximum absolute acceleration response $S_{a}$ and the maximum relative displacement response $S_{d}$ have the approximate relation,

$$
S_{a}=\omega^{2} S_{d}=\frac{k}{m} S_{d}
$$

in which $\omega$ represents undamped natural circular frequencies.

Thus, the following equation can be got from (2):

$$
F=m S_{a}=k S_{d}=V ;
$$

that is to say, the maximum seismic action $F$ can be equal to the base shear $V$.

Figure 20 plots the relationship between max base shear and peak acceleration under Wolong record input. It is clear that, with the increase of PGA, the max base shear of testing 
model approximately increased linearly. The fitting equation is given as follows:

$$
y=-4.40032+245.689 \times x,
$$

where $x$ denotes the peak acceleration and $y$ is max base shear. The value of adjusted coefficient of determination (Adj. $R$-Square) is close to 1 ; it indicates that the linear fit was good. The result shows that some of the structural members might be damaged under strong input motions, while the stiffness and strength of the model structure decreased slightly, and the RC frame with EPSC latticed concrete infill wall has satisfactory seismic performance under severe earthquakes in particular.

\section{Conclusions}

A series of shaking table tests were conducted to investigate the seismic performance of RC frame with EPSC latticed concrete infill wall. The results of the investigation presented in this paper are summarized as follows:

(1) RC frame with EPSC latticed concrete infill wall has satisfactory seismic performance, under severe earthquakes in particular. The test model was still in elastic state under input motion with PGA of $0.20 \mathrm{~g}$. The RC frame structure had no damage even if the PGA was up to $1.00 \mathrm{~g}$.

(2) The RC frame with EPSC latticed concrete wall is more sensitive to input motions with more high frequency components and long duration.

(3) EPSC latticed concrete wall provides higher stiffness, which could bear larger shear force and significantly reduce the story drift of the structure, and the walls could be equivalent to the RC shear wall. Meanwhile, the stiffness could be weakened for the latticed concrete infill walls with large openings.

(4) The horizontal and vertical rebar, arranged in the EPSC latticed concrete infill walls, could effectively restrain the cracks extending and provide sufficient connections to avoid the infill walls falling out of their surrounding RC frames. Meanwhile, the smaller the rebar spacing, the smaller the tensile strain measured.

To achieve a more comprehensive evaluation on the performance of RC frame with latticed concrete infill wall, more relative studies are expected, for example, comparing with conventional infill walls and developing a numerical model.

\section{Conflicts of Interest}

The authors declare that they have no conflicts of interest.

\section{Acknowledgments}

The authors gratefully acknowledge the financial support provided by National Key Technology Research and Development Program (2015BAK17B02), National Key Research and
Development Program of China (2016YFC402800), and the National Natural Science Foundation of China under Grants nos. 51608491 and 51421005.

\section{References}

[1] D. Celarec, P. Ricci, and M. Dolšek, "The sensitivity of seismic response parameters to the uncertain modelling variables of masonry-infilled reinforced concrete frames," Engineering Structures, vol. 35, pp. 165-177, 2012.

[2] T. Kalman Šipoš, V. Sigmund, and M. Hadzima-Nyarko, "Earthquake performance of infilled frames using neural networks and experimental database," Engineering Structures, vol. 51, pp. 113127, 2013.

[3] K. T. Tan, H. A. Razak, D. Lu, and Y. Li, "Seismic response of a four-storey RC school building with masonry-infilled walls," Natural Hazards, vol. 78, no. 1, pp. 141-153, 2015.

[4] P. Lukkunaprasit, A. Ruangrassamee, T. Boonyatee et al., "Performance of structures in the Mw 6.1 Mae Lao Earthquake in Thailand on May 5, 2014 and implications for future construction," Journal of Earthquake Engineering, vol. 20, no. 2, pp. 219242, 2016.

[5] L. Hermanns, A. Fraile, E. Alarcón, and R. Álvarez, "Performance of buildings with masonry infill walls during the 2011 Lorca earthquake," Bulletin of Earthquake Engineering, vol. 12, no. 5, pp. 1977-1997, 2014.

[6] K. Kawashima, Ö. Aydan, T. Aoki et al., "Reconnaissance investigation on the damage of the 2009 L'Aquila, Central Italy earthquake," Journal of Earthquake Engineering, vol. 14, no. 6, pp. 817841,2010

[7] F. Braga, V. Manfredi, A. Masi, A. Salvatori, and M. Vona, "Performance of non-structural elements in RC buildings during the L'Aquila, 2009 earthquake," Bulletin of Earthquake Engineering, vol. 9, no. 1, pp. 307-324, 2011.

[8] B. Zhao, F. Taucer, and T. Rossetto, "Field investigation on the performance of building structures during the 12 May 2008 Wenchuan earthquake in China," Engineering Structures, vol. 31, no. 8, pp. 1707-1723, 2009.

[9] O.-S. Kwon and E. Kim, "Case study: Analytical investigation on the failure of a two-story RC building damaged during the 2007 Pisco-Chincha earthquake," Engineering Structures, vol. 32, no. 7, pp. 1876-1887, 2010.

[10] G. Uva, F. Porco, and A. Fiore, "Appraisal of masonry infill walls effect in the seismic response of RC framed buildings: a case study," Engineering Structures, vol. 34, no. 1, pp. 514-526, 2012.

[11] GB 50003, Code for Design of Masonry Structures, China Architecture \& Building Press, Beijing, China, 2011.

[12] J. Kosny and P. Childs, "Validation of heating 7.2 simulations using hot box test data for RASTRA wall form system with expanded polystyrene-beads, Report No. ASHRAE 1 145-RP," Tech. Rep., Oak Ridge National Laboratory Buildings Technology Center, 2000.

[13] K. G. Babu and D. S. Babu, "Behaviour of lightweight expanded polystyrene concrete containing silica fume," Cement \& Concrete Research, vol. 33, no. 5, pp. 755-762, 2003.

[14] CECS 173, "Technical specification for dwelling houses with EPSC form latticed concrete wall," Tech. Rep., China Planning Press, Beijing, China, 2004.

[15] J. Zhou, P. Wang, X. Meng, J. Zhu, Y. Hou, and Z. Zhang, "Experimental study on seismic behavior of concrete grillage walls with different shear span ratio," Journal of Earthquake 
Engineering and Engineering Vibration, vol. 31, no. 3, pp. 127133, 2011 (Chinese).

[16] T. A. Shugar, "Preliminary analysis of reinforced concrete waffle walls, No. NFESC-TR-2068-SHR,” Tech. Rep., Naval Facilities Engineering Service Center Port Hueneme Ca, 1997.

[17] J. Sun, J. Qian, E. Fang, Q. Hu, and B. Feng, "Experimental study on seismic behavior of concrete grill wall with small shear span ratio," Journal of Building Structures, vol. 23, no. 2, p. 19, 2002 (Chinese).

[18] J. Zhou, Z. Wang, X. Meng, and Y. Yang, "Influence of aspects ratios on seismic behavior of recycled concrete lattice walls," Journal of Shenyang Jianzhu University (Natural Science), vol. 28, no. 2, pp. 241-248, 2012 (Chinese).

[19] W. D. Chen, G. X. Zhang, and B. Li, "Mechanical performance analysis of EPS new energy-conservation wall structure," Industrial Construction, vol. S1, pp. 170-172, 2007 (Chinese).

[20] GB50010., Code for design of concrete structures, China Architecture \& Building Press, Beijing, 2010.

[21] GB50011, Code for Seismic Design of Buildings, China Architecture \& Building Press, Beijing, China, 2010.

[22] X. J. Li, L. Liu, Y. S. Wang, and T. Yu, "Analysis of horizontal strong-motion attenuation in the great 2008 Wenchuan earthquake," Bulletin of the Seismological Society of America, vol. 100, no. 5 B, pp. 2440-2449, 2010.

[23] X. Lu, Y. Zhou, and F. Yan, "Shaking table test and numerical analysis of RC frames with viscous wall dampers," Journal of Structural Engineering, vol. 134, no. 1, pp. 64-76, 2008. 


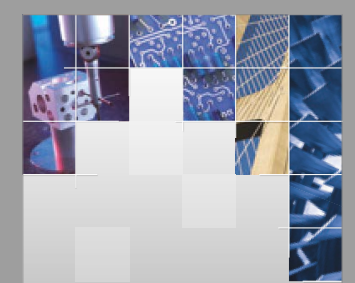

\section{Enfincering}
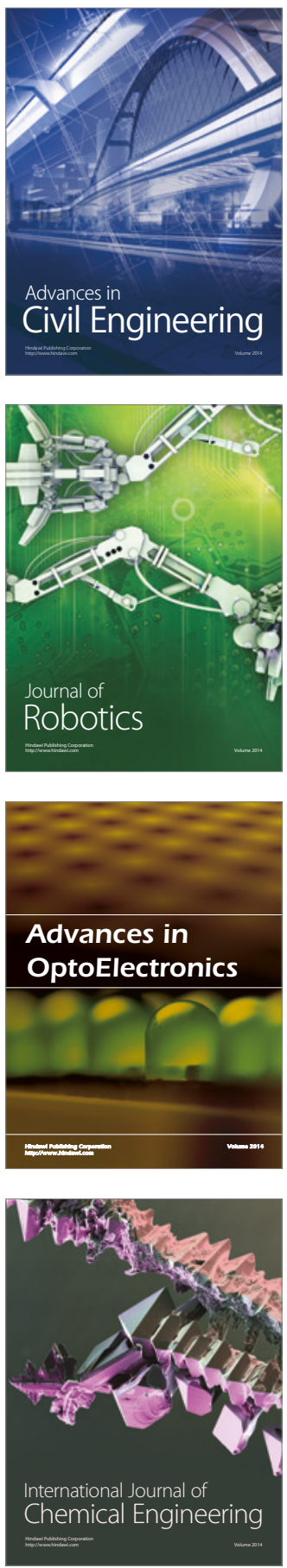

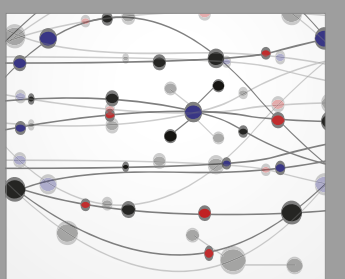

The Scientific World Journal

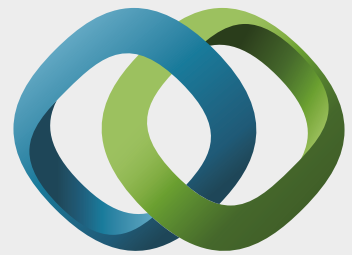

\section{Hindawi}

Submit your manuscripts at

https://www.hindawi.com
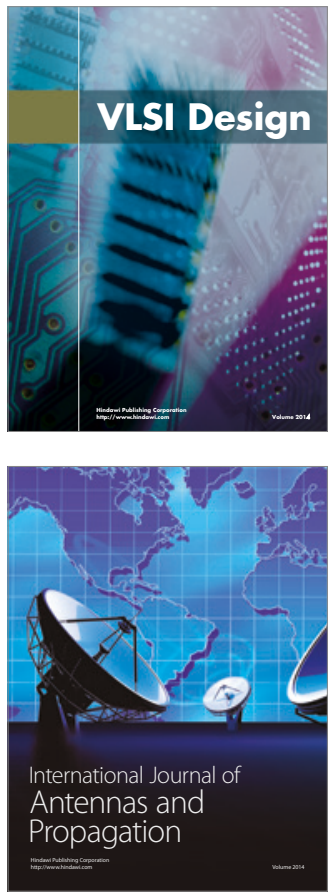

\section{Rotating}

Machinery
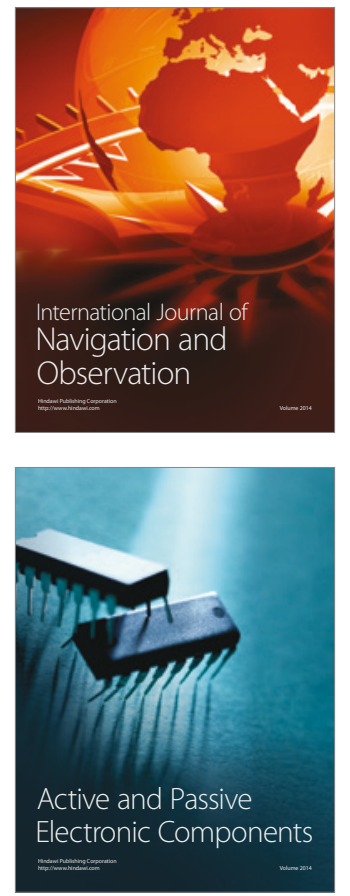
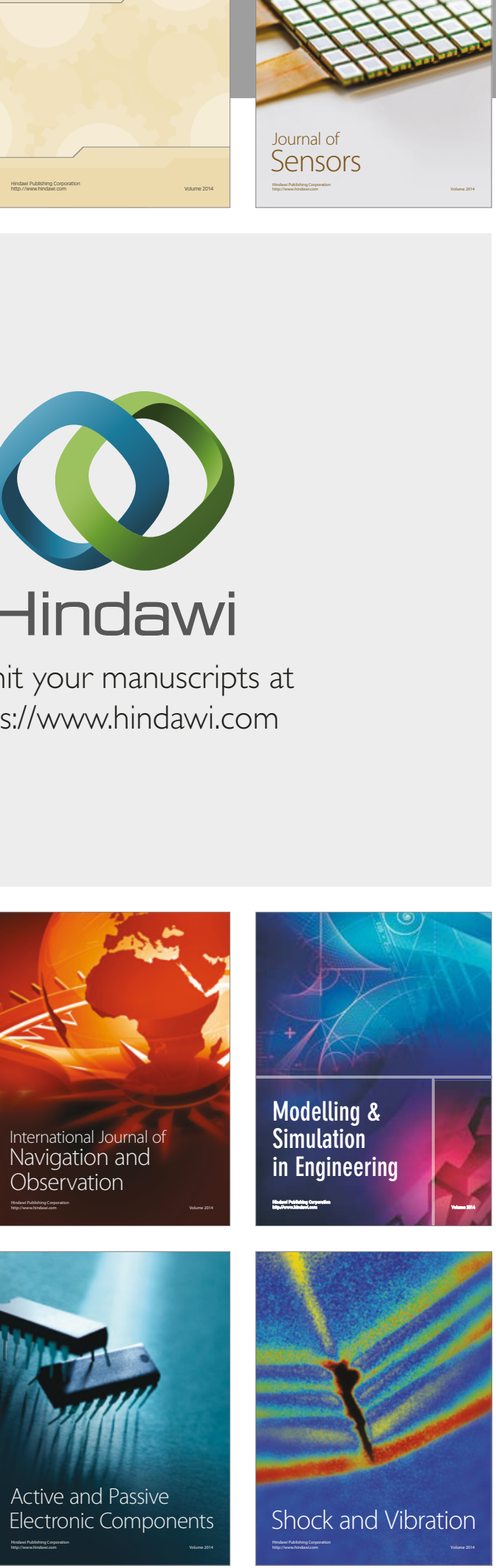
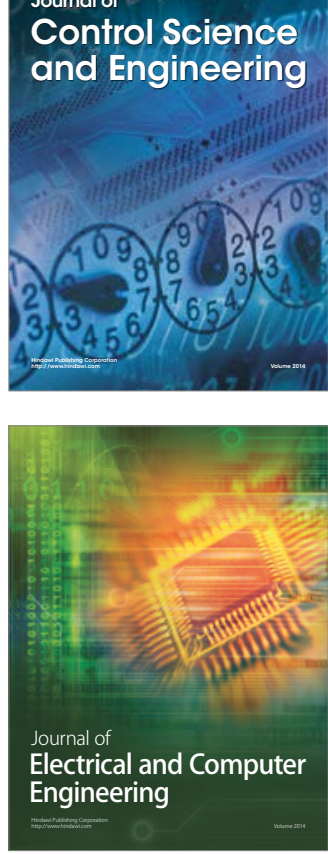

Distributed

Journal of

Control Science

and Engineering
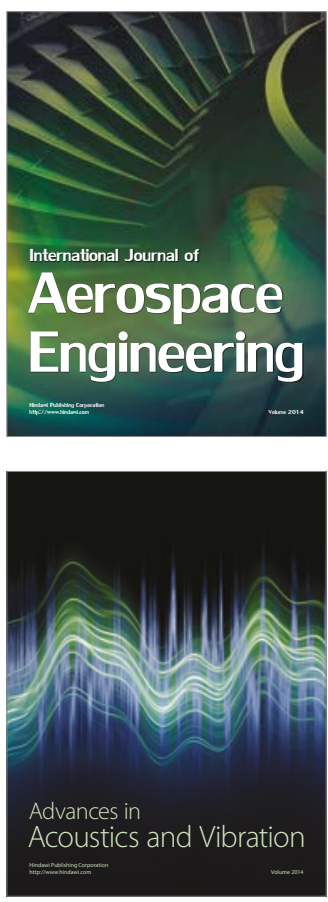

Sensor Networks 